\title{
A DYNAMIC STRUCTURAL MODEL OF CONTRACEPTIVE USE AND EMPLOYMENT SECTOR CHOICE FOR WOMEN IN INDONESIA
}

by

\author{
Uma Radhakrishnan * \\ U.S. Bureau of the Census
}

CES 10-28

September, 2010

The research in this paper was undertaken while the author was at University of Virginia.

The research program of the Center for Economic Studies (CES) produces a wide range of economic analyses to improve the statistical programs of the U.S. Census Bureau. Many of these analyses take the form of CES research papers. The papers have not undergone the review accorded Census Bureau publications and no endorsement should be inferred. Any opinions and conclusions expressed herein are those of the author(s) and do not necessarily represent the views of the U.S. Census Bureau. All results have been reviewed to ensure that no confidential information is disclosed. Republication in whole or part must be cleared with the authors.

To obtain information about the series, see www.ces.census.gov or contact Cheryl Grim, Editor, Discussion Papers, U.S. Census Bureau, Center for Economic Studies 2K130B, 4600 Silver Hill Road, Washington, DC 20233, CES.Papers.List@census.gov. 


\begin{abstract}
This research investigates the impact of the Indonesian family planning program on the labor force participation decisions and contraceptive choices of women. I develop a discrete choice dynamic structural model, where each married woman in every period makes joint choices regarding the method of contraceptive used and the sector of employment in which to work in order to maximize her expected discounted lifetime utility function. Each woman obtains utility from pecuniary sources, nonpecuniary sources, and choice-specific time shocks. In addition to the random shocks, there is uncertainty in the model as a woman can only imperfectly control her fertility. Dynamics in the model are captured by several forms of state and duration dependence. Women in this model make different choices due to different preferences, differences in observable characteristics, and realization of uncertainty. The choices made by a woman depend on the compatibility between raising children and the sector of employment (including wages). While making decisions regarding contraceptive use, a woman considers the trade-off between costs (monetary and nonmonetary) of having a child and the benefits from having one. The primary source of data for this study is the first wave of the Indonesia Family Life Survey (IFLS 1), a retrospective panel. In my research, I use the geographic expansion and the changing nature of the Indonesian family planning program as sources of exogenous variation to identify the parameters of the structural model. I estimate the model using maximum likelihood techniques with data from IFLS 1 for the periods 1979-1993. Structural model estimates indicate that informal sector jobs offer greater compatibility between work and childcare. Parameter estimates indicate that choices of contraception method and employment sector vary by exogenous characteristics.
\end{abstract}

JEL Codes: J13, J22, O17

Keywords: Family planning, female labor force participation, contraception, formal sector, Indonesia

*This research was supported by the Hewlett/IIE Paper Fellowship in Population, Reproductive Health, and Economic Development, grant no. 2007-1542. I would like to thank my advisors Steven Stern, Sarah Turner, and Leora Friedberg for their helpful comments and guidance. Special thanks to Christine Peterson for her help with Indonesia Family Life Survey data. I would like to thank David Newhouse and Arup Suryahadi for providing me with Minimum Wage data. All errors are mine. The research in this paper was undertaken while the author was at University of Virginia. Any opinions and conclusions expressed herein are those of the author and do not necessarily represent the views of the U.S. Census Bureau or University of Virginia. The research in this paper does not use any confidential Census Bureau information. 


\section{Introduction}

In the 1960s the average Indonesian woman had between five and six children; by the mid1990s, the average number of children had declined to close to three per woman. Figure 1 shows the decline in total fertility rate in Indonesia for the period 1965-2002 using Indonesian Demographic and Health Survey data. A large part of this reduction in the total fertility rate has been attributed to the extensive family planning program that was initiated in the late 1960s under the regime of President Suharto. Contraceptive use among married women increased from $5 \%$ in the late 1960 s to approximately $55 \%$ in the mid-1990s. Figure 2 shows the trend in modern contraceptive prevalence rate among married women in Indonesia for the period 19772006.

While the family planning program reduced fertility rates and increased contraceptive use, there has been very little investigation of the program's impact on other aspects of a woman's life such as labor force participation. In my research, I use the geographic expansion and the changing nature of the family planning program as sources of exogenous variation to identify model parameters.

Indonesia experienced rapid economic growth from the 1970s until late 1990s. This broadened the employment opportunities available to Indonesian women. Table 1 lists labor force participation rates by gender in rural and urban areas of Indonesia for 1971, 1980, and 1990. It can be seen that the rate of increase of female labor force participation is greater than male labor force participation in both urban and rural areas.

It was during the same period that the large-scale family planning program was implemented in stages across Indonesia. Availability of contraceptives further broadened the choices available to the women in Indonesia. However, what remained unchanged in Indonesia as in many developing countries is that women continue to hold the primary responsibility for 
taking care of children. I do not model the labor force participation decision of women in Indonesia, a developing country, as a binary decision as usually done in standard labor force participation models. I allow for choice of employment sectors. Large fractions of women who participate in the labor force are employed in the informal sector of the economy. The informal sector comprises of small-scale production and service activities that are individually or familyowned (Todaro 2000). Informal sector jobs, usually carried out at home or at close proximity to one's residence, are characterized by flexibility of hours, ability to choose the pace of work, and ease of entry and exit. ${ }^{1}$ Women may work in the informal sector due to the compatibility between work and family responsibilities, especially provision of childcare. Women face different costs of participation across sectors and, as a result, are not indifferent between where they work. It is reasonable to assume that women's motivation in controlling their fertility depends on the compatibility between raising children and the sector of employment. One can infer the degree of motivation women have in controlling their fertility based on the contraceptive method used.

One of the problems in studying joint choices is in determining the direction of causation. A woman may use contraceptives to delay or avoid birth in order to work in the formal sector. On the other hand, a woman may have used contraceptives and had fewer children; the small family size may then give her the flexibility to work in the formal sector. My research investigates how investments in family planning services affect the well-being of women by impacting their employment choices and child-bearing decisions, while at the same time recognizing the interdependency of these interrelated life choices. I use the exogenous variation in the timing of introduction of different types of contraceptive clinics as instruments for fertility to identify the causal relationship between employment and contraception choices.

1 On average, informal sector jobs do not pay as much as formal sector jobs. 
In addition, I use the exogenous variation in minimum wage rates over time and across provinces as instruments for employment sector choice to further aid in identification.

This research formulates and estimates a dynamic structural model in which employment sector and use of contraceptives are choice variables. I model the behavior of married women as a finite horizon, discrete choice, dynamic programming problem. ${ }^{2}$ In each period, each woman chooses the contraception method and the employment sector to maximize her expected discounted lifetime utility function. She obtains utility from pecuniary sources, nonpecuniary sources, and choice-specific time shocks. In addition to the random shocks, there is uncertainty in the model as women can only imperfectly control their fertility. Women in this model make different choices due to different preferences, differences in observable characteristics, and realization of uncertainty. Several forms of state and duration dependence capture dynamics in the model. The choices made by women depend on the compatibility between raising children and the sector of employment (including wages). While making decisions regarding contraceptive use, a woman considers the trade-off between costs (monetary and nonmonetary) of having a child and the benefits from having one.

I study the impact of exposure to a family planning program on the following direct behavioral responses: spacing of births and number of children. In addition, I examine the impact of the family planning program on labor force participation of women, which depends on both their past and future ability to control fertility. Access to different methods of contraceptives provides the woman better control over her fertility and thus helps in preventing unwanted births. This widens the employment choices that the woman faces. For instance, the

2 I do not treat marital decisions as endogenous for two reasons: first, it increases the complexity of estimating the dynamic model; and second, I do not have an identification strategy to deal with it. Traditional marriages in Indonesia are arranged by parents, with girls having very little choice in the selection of their spouse. 
impact of availability of modern contraceptives not only increases the probability that the woman participates in the labor force but also increases the likelihood that the woman is employed in the formal sector of the economy. Availability of modern methods of contraception increases the wage rates that women can earn, an effect I have endogenized in my model.

I estimate the model using maximum likelihood techniques with data from the first wave of Indonesia Family Life Survey 1 (IFLS 1) for the period, 1979 to 1993 . This survey is a retrospective panel containing data at both the individual and family levels on contraception, fertility, health, and labor force activities. In addition to the household surveys, IFLS 1 includes community surveys that can be linked to all households and individuals.

\section{Family Planning Program in Indonesia}

The family planning program spread across Indonesia in three stages under three fiveyear development plans. ${ }^{3}$ In the first stage (1970-74), the program was introduced in the provinces of West Java, Jakarta, Central Java, East Java, Yogyakarta, and Bali. ${ }^{4}$ In the second stage (1975-79), the program was introduced in 10 other provinces belonging to the Outer Islands $1 .{ }^{5}$ In the third stage (1980-84), the family planning program was introduced in Outer Islands 2, which constitutes the rest of the provinces in Indonesia. ${ }^{6}$ Figures 3 to 5 show the geographic expansion of the family planning program across Indonesia. ${ }^{7}$ Since the start of the family planning program, users have been obtaining contraceptives either free of charge or at a

\footnotetext{
3 The primary sources of obtaining contraception in Indonesia include the following: 1) government health centers; 2) private practitioners such doctors and midwives; 3 ) government and private hospitals; 4) village integrated health posts; 5) family planning distribution points; and 6) pharmacies.

${ }^{4}$ West Java, Jakarta, Central Java, East Java, and Yogyakarta are provinces that are located in Java.

${ }^{5}$ These provinces include Aceh, North Sumatra, West Sumatra, South Sumatra, Lampung, North Sulawesi, South Sulawesi, South Kalimantan, West Kalimanatan, and West Nusa Tenggara.

${ }^{6}$ Outer Islands 2 include: Riau, Jambi, Bengkulu, East Nusa Tenggara, Central Kalimantan, East

Kalimantan, Central Sulawesi, South East Sulawesi, Maluku, Irian Jaya, and East Timor.

${ }^{7}$ See notes associated with figures 3-5.
} 
subsidized rate. In 1989, the government launched the KB Mandiri (Self-Reliant Family

Planning) in urban areas where contraceptives could be obtained from private sector providers for a fee.

The family planning program initially followed a clinic-based approach. The family planning program under the clinic-based approach was implemented through the community health centers (puskemas) that were established at the sub-district level. In the early 1970s in Java and Bali, family-planning field workers, who earlier worked at the clinics, were shifted to the villages so that they would be able to reach a broader client base. Field workers were placed only in Java and Bali as these were the most densely populated areas and distance between villages was not too great. In the mid 1970s, the community-based approach was established to complement the clinic-based approach. The realization that the clinic-based approach failed to reach a large group of target women resulted in the adoption of a community-based approach (Shrestha 2007). This was done to encourage contraceptive use, increase family planning awareness, and to facilitate a system of supplying contraceptives at a village level. Moreover, this made it possible for the family planning workers to reach out to prospective clients as opposed to waiting for the clients to come back to the clinic. A key idea of the community-based approach was to use the existing village institutions to promote the idea of family planning. ${ }^{8}$ The community-based approach was further aided by the family welfare movement ${ }^{9}$ and family planning kaders ${ }^{10}$, usually led by wives of government officials. In addition to encouraging people to use contraceptives, efforts were made to ensure existing users did not

\footnotetext{
${ }^{8}$ For instance, banjar, a traditional institution was used in Bali to promote family planning by training banjar heads. In Java, local officials were used to promote family planning, as traditional institutions were not as strong as that in Bali.

${ }^{9}$ The family welfare movement was started in the 1960 s to alleviate poverty in Indonesia. It is an organization of women who are married to public servants.

${ }^{10}$ Kaders are women health volunteers.
} 
discontinue use of contraceptives. This resulted in the development of the family planning distribution point (PKKBD) in 1975 11, managed by the village family planning management assistant. As stated in Lubis (2003), the family planning distribution points are full-fledged community family planning posts. ${ }^{12}$ In addition, as the family planning program developed, community-based groups became involved in encouraging contraceptive use and supplying contraceptives at the village level. In the late 1970s, the development plan focused on nutrition of children. This led to the establishment of nutrition posts at a village level, which weighed children and provided awareness related to their nutrition. The National Family Planning Coordinating Board (BKKBN) in the mid-1980s recognized the possibility of using these nutrition posts to promote family planning. This resulted in the established of village integrated health posts (posyandus) that has become the central activity of the community-based approach of family planning. ${ }^{13}$ In this research, I use the variation in timing of introduction of community health centers, family planning distribution point, and village integrated health posts across Indonesia as instruments that aid in the identification of the model parameters.

Table 2 shows the increase in the number of contraceptive users for the period 1973 to 1990 in the provinces of Java and Bali, Outer Islands 1, and Outer Islands 2.14 In 1973-74, the clinic-based approach of family planning program was introduced only in Java and Bali where there were 1.6 million users. In the second five-year plan, the number of contraceptive users in Outer Islands 1 was nearly 0.5 million and the number of contraceptive users in the provinces of Java and Bali increased to 5 million, where the family planning program had shifted to a

\footnotetext{
${ }^{11}$ PKKBD is also referred to as village contraceptive distribution center (VCDC). 12 These are distribution centers for contraceptives staffed by village volunteers.

${ }^{13}$ Village integrated health posts are monthly activities organized by volunteers and attended by family planning workers and health staff (Frankenberg et al 2003). They are open only one morning per month and are held at the home of one of the volunteers or in the village hall (Frankenberg et al 2003).

14 Table 2 is quoted from Shrestha (2007). The source of this data is BKKBN (1992).
} 
community-based approach. During the third five-year plan, family planning was introduced in Outer Islands 2 where the number of contraceptive users was 0.5 million. During 1983-84 and 1989-90, the number of contraceptive users increased substantially in all provinces. Table 2 suggests lagged effects of access to contraceptives on number of contraceptive users.

\section{Literature Review}

This paper can be classified as belonging to the following branches of literature. First, many researchers have investigated the impact of family planning programs in developing countries on fertility and socio-economic outcomes (Gertler and Molyneaux 1994; Rosenzweig and Schultz 1982). Second, there have been several studies in the United States on the impact of birth control on fertility and other socio-economic outcomes of young women (Goldin and Katz 2002; Bailey 2006). Third, contraceptive behavior has been separately studied in both static (Easterlin and Crimmins 1985) and dynamic (Newman 1985; Montgomery 1988; Carro and Mira 2002) settings. Fourth, several studies have looked at female labor force participation in developing countries, where a considerable fraction of the labor force is engaged in the informal sector of the economy (Jaffe and Azumi 1960; Hill 1983). Fifth, many researchers have investigated the joint nature of labor supply and fertility decisions in both static (Fleisher and Rhodes 1979; Rosenzweig and Schultz 1985; Cain and Dooley 1976) and dynamic frameworks (Moffitt 1984; Hotz and Miller 1988; Francesconi 2002). Contraceptive use and labor force participation have also been studied in dynamic models, where other related life choices such as marriage and education are also modeled (Sylvester 2007).

My research contributes to the literature on female labor supply and contraceptive choice in several ways. First, I model the behavior of women in a developing country. A large fraction of women in developing countries are employed in the informal sector of the economy. A 
distinction is made between formal and informal sectors of employment in terms of both pecuniary and nonpecuniary returns. To make the model realistic, I model the choice of employment sector. Second, I combine choices of contraceptive methods with choices of employment sector. I allow the joint choice of contraception and employment sector in order to understand the compatibility between family responsibility and employment sector. Third, the wage rate is endogenous in the model. Fourth, the model allows for control over fertility in every period by allowing the women to choose from different methods of contraception; however, the control is imperfect because there is randomness introduced in the birth function. Fifth, the model allows for unobserved time-invariant preference heterogeneity, unobserved ability levels, and unobserved natural fecundity levels. Finally, my model combines features of the supply and demand models by allowing the woman to obtain utility from the interaction of the number of children and the method of contraceptive used.

\section{Economic Model}

\subsection{Choice Set}

I consider a finite horizon problem in which married women in each period make discrete choices regarding contraceptive methods and sector of employment to maximize their expected discounted lifetime utility. ${ }^{15} \mathrm{~A}$ woman in this model chooses one out of three contraceptive choices, denoted $\mathrm{m}_{\mathrm{t}}$ in each period $\mathrm{t}$. The choices are a modern method $(\mathrm{m}=1), \mathrm{a}$ traditional method $(\mathrm{m}=2)$, and no contraception $(\mathrm{m}=3)$. Modern methods include implants,

\footnotetext{
${ }_{15}$ Bias associated with selection based on marital status may be less of an issue in the Indonesian context as most marriages are arranged by parents when their daughters are young. The proportion of women who remain single at any given age is lower in Indonesia compared to its neighboring countries. It has been empirically observed that, in 1990, less than 5\% of women aged 30-34 were single in Indonesia, compared to $13.4 \%$ in Philippines and $14.1 \%$ in Thailand (Jones 2002). The median age of marriage for women in Indonesia was 20.9 years.
} 
IUDs, pills, injections, and condoms. Traditional methods include rhythm, withdrawal, traditional herbs, and any other method that does not require a visit to the family planning clinic. Classification into modern and traditional methods is based on two criteria: first, effectiveness of the methods in preventing pregnancies; and, second, only access to modern methods requires presence of a family planning program. Let $\mathrm{k}_{\mathrm{t}}$ denote sector of employment chosen in period $t$. The choice of sector is limited to the formal sector $(k=1)$, the informal sector $(\mathrm{k}=2)$, and not working $(\mathrm{k}=3)$. It is assumed that, in every period, a woman receives job offers from both job sectors and gets to choose from the various alternatives. Formal sector workers include government employees, private workers, and individuals who are self-employed with permanent workers. Informal sector workers include self-employed workers, self-employed individuals with temporary workers, and family workers. I have classified the sectors into "formal" and "informal" based on the compatibility between job and family responsibility. Informal sector jobs may provide an environment for taking care of children even while at work.

\subsection{Utility Function and Budget Constraint}

At each time $t$, the woman experiences nonpecuniary utility $\mathrm{q}_{\mathrm{t}}$, a choice-specific random shock $\xi_{\mathrm{kmt}}$, and pecuniary utility from consumption of a composite commodity $\mathrm{c}_{\mathrm{t}}$. Nonpecuniary utility includes utility from number of births ${ }^{16}$, age of the youngest child, duration in a particular state, unobserved preference heterogeneity, and utility from the interactions of exogenous characteristics with the choices made. Let $\mathrm{N}_{\mathrm{t}}$ denote the total number of births for a woman such that

$$
N_{t}=N_{t-1}+n_{t}
$$

\footnotetext{
${ }^{16}$ Women obtain utility from number of births as opposed to number of children. This is because I do not model child death.
} 
Let $r_{t}$ denote the age of the youngest child. ${ }^{17}$ It evolves according to

$$
r_{t}=\left\{\begin{array}{ccc}
r_{t-1}+1 & \text { if } & n_{t}=0 \\
0 & \text { if } & n_{t}=1
\end{array} .\right.
$$

The amount of childcare responsibility that a woman has depends to a large extent on the age of the youngest child and the number of children. I allow interactions of the age of youngest child with sector of employment in the utility function. Several demographic studies show that spacing births improve both mother's and infant's health. ${ }^{18}$ Let $b_{t}$ represent the number of periods before which the previous birth occurred. Yet another source of nonpecuniary utility is the duration for which an individual worked in a particular sector or used a certain method of contraception. Let $O_{t-1}^{k}$ denote the total number of periods that an individual worked in sector k until time t. These evolve according to

$$
O_{t}^{k}=O_{t-1}^{k}+o_{t}^{k}
$$

where $o_{t}^{k}$ is a dichotomous variable equal to one if the person was employed in sector $\mathrm{k}$ in period $t$ and equal to zero otherwise. The duration term may pick up nonpecuniary benefits of being in the same sector as a result of sector-specific human capital accumulation. Let $\vec{o}_{t}=$ $\left(o_{t}^{1}, o_{t}^{2}, o_{t}^{3}\right)$ and $\vec{o}_{t-1}=\left(o_{t-1}^{1}, o_{t-1}^{2}, o_{t-1}^{3}\right)$ denote the vectors that represent choice of employment sector in period $t$ and $t-1$, respectively. Similarly, the duration term for using a particular method of contraceptive may capture the ease of using a particular method. It is reasonable to assume that, the longer an individual uses a particular method, the more efficiently she may

\footnotetext{
${ }^{17}$ I keep track of only age of the youngest child. Keeping track of ages of all children would increase the size of the state space significantly and therefore cost of estimation.

18 Several studies sponsored by United States Agency for International Development (USAID) using Demographic and Health Survey (DHS) data show that spacing improves maternal and child health. In addition, birth spacing also reduces the incidence of child mortality (Miller et. al 1992; Forste 1994).
} 
learn to use it. Let $M_{t-1}^{m}$ denote the total number of periods the individual used contraceptive method $m$ until time $t$. These evolve according to

$$
M_{t}^{m}=M_{t-1}^{m}+m_{t}^{m}
$$

where $m_{t}^{m}$ is a dichotomous variable equal to one if the person used contraceptive method $\mathrm{m}$ in period t. Let $\vec{m}_{t}=\left(m_{t}^{1}, m_{t}^{2}, m_{t}^{3}\right)$ and $\vec{m}_{t-1}=\left(m_{t-1}^{1}, m_{t-1}^{2}, m_{t-1}^{3}\right)$ denote the vectors that represent choice of employment sector in period $t$ and $t-1$, respectively. Let $D_{t-1}=\left[O_{t-1}^{1}, O_{t-1}^{2}, O_{t-1}^{3}, M_{t-1}^{1}, M_{t-1}^{2}, M_{t-1}^{3}\right]$ denote the vector that represents the duration components. ${ }^{19}$ Nonpecuniary utility also depends on unobserved preference heterogeneity terms $\mu_{q}^{i}=\left\{\mu_{o}^{i}, \mu_{m}^{i}\right\}$ for employment sector and contraceptive method. These terms are treated as heterogeneous across the population but constant over time. These permanent unobserved heterogeneity terms help explain why some women never work or never use any contraception.

Nonpecuniary utility is also a function of observable exogenous characteristics such as the religion of the woman, urban or rural location, the province in which the women resides, her education level, and the age of the woman. ${ }^{20}$ Let this be denoted by vector $\mathrm{X}_{\mathrm{t} .}$ I allow for interaction of observable exogenous characteristics of a woman with choices she makes. The nonpecuniary utility function is specified as

\footnotetext{
${ }^{19}$ I do not model sector-specific human capital depreciation for the years in which a woman does not work in a particular sector. It may be the case that rate of depreciation varies across sectors. Keane and Wolpin (1997) model skill depreciation during periods of non-work and allow this to vary by occupations.

${ }^{20}$ I allow for only two province classifications: Java and non-Java. However, IFLS 1 covers 13 Indonesian provinces.
} 


$$
\begin{aligned}
& \mathrm{q}_{\mathrm{kmt}}=\mathrm{a}_{1 \mathrm{~km}} o_{t}^{k} \mathrm{X}_{\mathrm{t}}+\mathrm{a}_{2 \mathrm{~km}} m_{t}^{m} \mathrm{X}_{\mathrm{t}}+\mathrm{a}_{4} O_{t}^{k} O_{t-1}^{k}+\mathrm{a}_{5} m_{t}^{m} M_{t-1}^{m}+\mathrm{a}_{6} \mathrm{~N}_{\mathrm{t}}+ \\
& \mathrm{a}_{7} \mathrm{~b}_{\mathrm{t}} \mathrm{n}_{\mathrm{t}}+\mathrm{a}_{8} \mathrm{n}_{\mathrm{t}-1}+\mathrm{a}_{9}(\mathrm{t}>35) \mathrm{n}_{\mathrm{t}}+\mathrm{a}_{10} o_{t}^{k} \mathrm{n}_{\mathrm{t}-1}+\mathrm{a}_{11} \mathrm{~N}_{\mathrm{t}} o_{t}^{k}+\mathrm{a}_{12} \mathrm{r}_{\mathrm{t}} o_{t}^{k}+\mathrm{a}_{13} m_{t}^{m} \mathrm{n}_{\mathrm{t}-1}+\mathrm{a}_{14} \mathrm{~N}_{\mathrm{t}} m_{t}^{m} \\
& \mathrm{a}_{15} \mathrm{r}_{\mathrm{t}} m_{t}^{m}+\mathrm{a}_{16} m_{t}^{m} \mathrm{X}_{\mathrm{c}}+\mu_{o}^{i}+\mu_{m}^{i} 21
\end{aligned}
$$

A woman obtains pecuniary utility from the consumption of a composite commodity, $c_{t}$.

A woman has income from the following sources: wages $w_{t}^{k}$ if employed in the formal or informal sector, husband's income $w_{t}^{h}$, and combined unearned income of husband and wife $Y_{t}{ }^{22}$ The earnings of the husband are observed in the data. Expenditures include purchase of a composite commodity with price equal to one, expenses $P_{m}$ associated with contraceptive use, and expenses $P_{n}$ related to bringing up children, multiplied by the total number of children. I assume that the private consumption enjoyed by a woman is a given fraction of the difference between the family pooled income and expenditure on contraception and children. I assume that this fraction, the sharing rule parameter $\psi$, is $0.5 .^{23}$

The maximization problem in each period is subject to the budget constraint

$$
c_{t}=\psi *\left[w_{t}^{k}+w_{t}^{h}+Y_{t}-P_{m} m_{t}^{m}-P_{n} N_{t}\right]
$$

The wage equation is a function of schooling $\mathrm{G}$, age, local labor market conditions $X_{t}^{L}$ represented by the minimum wage rate at the province level, experience in the formal

\footnotetext{
22 Non-wage earnings are observed if the woman is in the informal sector.

${ }^{23}$ Assigning the sharing rule parameter to be 0.5 is arbitrary. Several studies show mothers, on average, care more about children than fathers (Schultz 1990; Thomas, Contreras, Frankenberg 2002). These studies are based on the empirical observation that increasing mother's bargaining power results in better outcome for children. An alternative would be to make the sharing rule parameter a function of exogenous characteristics. However, the identification of the sharing rule requires data on assignment of a private good to one of the spouses (Browning et. al 1994).
} 
sector $O_{t-1}^{1}$, experience in the informal sector $O_{t-1}^{2}$, and a random wage shock $\varepsilon_{t}^{k}$. Let $\varepsilon_{t}=\left\{\varepsilon_{t}^{1}, \varepsilon_{t}^{2}\right\}$

be the vector of wage errors. The wage also depends on $\mu_{w}^{i}$, which is the unobserved ability to

work. This varies across individuals but is constant over time. The wage for a nonworking woman is assumed to be zero, and the wage structure for $k=\{1,2\}$ is

$$
w_{t}^{k}=w_{k 0}+\theta_{k 1} G+\theta_{k 2} t+\theta_{k 3} X_{t}^{L}+\theta_{k 4} O_{t-1}^{1}+\theta_{k 5} O_{t-1}^{2}+\varepsilon_{t}^{k}+\mu_{w}^{i}, \mathrm{k}=1,2 .
$$

The final component of the utility function is the choice-specific time shock. Let $\xi_{\mathrm{kmt}}$ be the shock, which is assumed to have an independent extreme value distribution. The objective of each woman is to maximize her expected discounted lifetime utility

$$
E\left[\sum_{t=A_{0}}^{T^{F}} \beta^{t-A_{0}} U\left(\vec{o}_{t}, \vec{o}_{t-1}, \vec{m}_{t}, \vec{m}_{t-1}, n_{t}, D_{t-1}, r_{t}, X_{t}, c_{t}, N_{t}, b_{t}, \mu_{q}^{i}, \xi_{k m t}\right)\right]
$$

where $E$ is the expectation operator, $\beta$ is the discount factor, and $X_{t}$ is the vector of observable characteristics. The utility function of the woman in a particular period $t$ when she chooses $d_{k m t}$ is

$$
U\left(d_{k m t}\right)=c_{t}+q\left(\vec{o}_{t}, \vec{o}_{t-1}, \vec{m}_{t}, \vec{m}_{t-1}, n_{t}, D_{t-1}, r_{t}, X_{t}, N_{t}, b_{t}, \mu_{q}^{i}\right)+\xi_{k m t}
$$

where $\mathrm{q}($.$) is the nonpecuniary utility function and \xi_{\mathrm{kmt}}$ is the choice-specific time shock to utility.

\subsection{Birth Probability Function}

I introduce another source of randomness in this model through the birth function. The probability that a birth will occur in period $\mathrm{t}+1$ when contraceptive method $m_{t}^{m}$ is equal to 1 in period $t$ is

$$
F_{m, t+1}=\Phi\left(t, m_{t}^{m}, M_{t}^{m}, \mu_{f}^{i}\right)
$$


where $\Phi$ is the normal distribution function. The probability of birth depends on the age of the woman, the method of contraception used, the duration for which the method was used, and the unobserved natural fecundity level $\mu_{f}^{i}$. The permanent unobserved fecundity term might

help in explaining why some women never have children.

\subsection{State Space and Value Functions}

The lifetime utility maximization problem can be expressed using value functions. The decision at a particular point $t$ depends on the contraceptive choice, employment, and birth history of the woman until that point. The state at $\mathrm{t}$ is

$$
S(t)=\left(\vec{o}_{t-1}, \vec{m}_{t-1}, D_{t-1}, r_{t-1}, N_{t-1}, b_{t}, t, \xi_{t}, \varepsilon_{t}\right) .
$$

The value function of a given choice provides the woman's lifetime discounted value of that particular choice. The value function of a woman at time $t$, given state $S(t)$ and unobserved heterogeneity $\mu_{i}$, is

$$
\begin{aligned}
& V_{t}=\max \left[V_{1,1, t}\left(S(t), \mu_{i}\right), \ldots, V_{3,3, t}\left(S(t), \mu_{i}\right)\right] \text { where } \\
& V_{k, m, t}\left(S(t), \mu_{i}\right)=U_{k m t}\left(S(t), \mu_{i}\right)+\beta E V_{t+1}\left(S(t+1), \mu_{i} \mid S(t), d_{k m t}=1\right) \text { for } \mathrm{A}_{0} \leq \mathrm{t}<\mathrm{T}^{*} \\
& V_{k, m, T^{*}}=\sum_{t^{\prime}=T^{*}}^{T^{*}} \beta^{t^{\prime}-T^{*}} U_{k m t^{\prime}}\left(S\left(t^{\prime}\right), \mu_{i}\right) \text { for } \mathrm{T}^{*} \leq t^{\prime} \leq \mathrm{T}^{\mathrm{F}}
\end{aligned}
$$

In the above equations, $\mathrm{V}_{\mathrm{k}, \mathrm{m}, \mathrm{t}}$ denotes the alternative-specific value function associated with sector $\mathrm{k}$ and method $\mathrm{m}$ in period $\mathrm{t}$. At every period $\mathrm{t}$, a woman has full knowledge of her exogenous characteristics, her past choices, employment sector and contraception method duration terms, and past and contemporaneous realization of wage errors and extreme value errors. Although a woman does not know the future realization of error terms, she knows the distribution of these errors. Expectations are taken with respect to the future choice-specific 
random shock to utility, future wage offer shocks, and randomness in births. The unobserved heterogeneity is known to the woman, but unknown to the econometrician.

\section{Data: Indonesia Family Life Survey 1}

The primary data source for this study is the first wave of the Indonesia Family Life Survey IFLS 1 (1993). ${ }^{24}$ This survey is a retrospective panel containing data at both the individual and family levels on contraception, fertility, health, and labor force activities. In addition to the household surveys, IFLS 1 includes community surveys that can be linked to all households. The sampling framework is stratified on provinces, and then enumeration areas (EAs) are randomly selected within the provinces. Households are then randomly selected within the EAs, and then respondents are selected within the households. ${ }^{25}$ The EAs are randomly selected from a nationally representative sampling frame used in SUSENAS 1993, a socioeconomic survey covering 60,000 households. Urban areas EAs and EAs in smaller provinces were oversampled to enable urban-rural and Javanese-Non-Javanese comparisons. ${ }^{26}$

The 1993 sample consists of 7,730 households drawn from 321 randomly selected EAs, ${ }^{27}$ spread across 13 of the 26 Indonesian provinces. Figure 6 shows the IFLS 1 provinces in Indonesia. The 13 IFLS 1 provinces cover $83 \%$ of the country's population and much of its cultural diversity. The provinces were chosen to achieve a certain level of cultural and socioeconomic diversity at a minimum cost.

\footnotetext{
${ }^{24}$ See http://www.rand.org/labor/FLS/IFLS/.

${ }^{25}$ The following selection rule was used in choosing members of household: "The household head and his or her spouse; two randomly selected children (biological, step, adopted, or fostered) of the head and spouse, aged 0 to 14 (interviewed by proxy); an individual aged 50 and above, randomly selected from remaining members, and his or her spouse; and for a randomly selected 25 percent of the households, an individual aged 15 to 49 randomly selected from remaining members, and his or her spouse." (IFLS newsletter November 95 (2)). Weights are in IFLS dataset to adjust for respondent selection rules. ${ }^{26}$ Sampling weights are provided with the data to adjust for the oversampling.

${ }^{27}$ A given community can have more than one EA. There are 321 EAs, but only 312 communities.
} 
In order to obtain my final sample of women, I start with 4,890 ever-married women drawn from across 13 provinces. ${ }^{28}$ Next, I drop women with missing and inconsistent responses. In addition to this, I restrict my sample to women who get married during or after 1979. I do this as I do not observe contraceptive choices made in the 1960s and 1970s. ${ }^{29}$ The final sample includes 2,067 ever-married women aged 16 to 46 years in 1993. Table 3 shows the construction of the sample. The mean age of the women in 1993 is 27.7 years. I keep track of each woman from the year in which she was married up to the year 1993. This results in a total of 20,707 woman-years. On average, I observe a woman in the sample for 10 years. The mean age at the time of marriage is 19.7 years. The distribution of the final sample across the different provinces is given in Table 4, and descriptive statistics are given in Table 5.

A complete fertility summary was obtained for all women, including the outcome of pregnancies and the year of birth. This enables me to create indicator variables for every year after marriage during which the woman gave birth and then calculate the number of births the woman has had in total up to that particular year for all the years since marriage. ${ }^{30}$ This information is used to construct the child spacing variable, which is the number of years from the time of marriage to the first birth or the number of years between each birth. The average number of children per woman in the sample is 2.44 . The total number of children for all the women in the sample is 4,160 . The average age of the youngest child for woman-year observations in my sample is 2.07 years.

\footnotetext{
${ }^{28}$ In the appendix, I discuss imputation methods used to deal with missing choice variables and income information.

${ }^{29}$ Gertler and Molyneaux (1994) note that the family planning programs in Indonesia had a significant impact on the reduction in fertility in the 1980s and early 1990s.

${ }^{30} \mathrm{In}$ Indonesia, there is stigma attached to premarital pregnancies. Women in my final sample have not given births before marriage (comparing year of birth of children with year of marriage). This may be because of not reporting premarital births.
} 
Table 6 provides the distribution of woman-year observations across contraceptive and employment sector choices. The measure of contraceptive use is the method of contraceptive that the woman uses every period as obtained from the contraceptive calendar found in IFLS 1. A monthly five-year retrospective calendar was given to women whose first marriage was before 1984. For women married after 1984, which is nearly $53 \%$ of the sample, the contraceptive calendar covers the entire period after marriage. I group the different methods of contraceptives used into three broad categories: modern method, traditional method, and not using any method. Modern methods include pills, condoms, IUDs, and injection. Traditional methods include methods such as rhythm, withdrawal, and herbs that do not require visits to the clinic. I convert the monthly contraceptive use information to yearly information using the following guidelines: First, if more than one method is used, then the method that is used the most number of times is considered as the method used for that year; and second, if only one method is used in a year (it could be for one month, two months, or twelve months) that method is considered as the method for that year. In the year 1993, 38\% of the sample did not use any form of contraceptives, nearly $5 \%$ of the sample used traditional methods, and the remaining $57 \%$ used modern methods.

Individuals are asked extensive questions on their current and retrospective labor market experiences. ${ }^{31}$ Detailed information including occupation, type of employer, industry, hours of work, and wages, is recorded from the period, 1987 to 1993, on an annual basis for both the woman and her spouse. Similar information, where appropriate, is also recorded for the first

\footnotetext{
${ }^{31}$ In my empirical analysis, I do not include data regarding secondary jobs. $6 \%$ of the sample has more than one job.
} 
job held, for the job held in 1983, and for the job held in 1973. ${ }^{32}$ I categorize employment choice by the sector in which a woman is employed: formal, informal, and not working. For the year 1993, nearly $35 \%$ of the sample is employed in the informal sector, almost $49 \%$ of the sample does not work, and the remaining $16 \%$ are employed in the formal sector. In addition, there is data on unearned income of the respondents.

The IFLS data enables me to identify the EA and province that each respondent lives in. In addition, there is information on whether the person lives in an urban or rural area. In 1993, the sample was almost evenly split between urban and rural areas. The detailed migration history in the IFLS helps in identifying the EA each woman lives in every period. This allows me to link each woman with the family planning program in the community that she resides in every period. 33

Community-level information was collected from the village (community) leader and from the head of the village women's group for each of the 321 EAs. In addition, data is collected from heads of several educational and health facilities in each EA. Community-level data include both current and historical data. An important feature of this data set is that the household-level data can be linked to the community-level data. This availability of community-level data allows me to know when the community-level programs were introduced, and thereby enables me to study its impact on the community.

In my empirical analysis, I use the following three measures of access to contraceptives in each EA: community health centers (puskemas), family planning distribution points (PKKBD), and the village integrated health posts (posyandu). The community health

\footnotetext{
${ }^{32}$ Data on employment sector choice is not collected for every period. The employment sector choice is simulated for the years in which the data has not been collected. A detailed description is provided in the appendix.

${ }^{33}$ Although theoretically straightforward, I do not model location decisions as it increases the computational cost of estimation. I assume that the woman lives in the EA she lived in during 1993.
} 
centers were established across the different provinces in three stages under the clinic-based family planning approach. They are physician-headed clinics that provide subsidized primary health care (Frankenberg 2003). The family planning distribution points were set up at the village level to be able to provide contraceptives more easily to the local population. Village integrated health posts, one of the central activities of the community-based approach of family planning also distributes contraceptives at the community level. Village integrated health posts are monthly activities organized by volunteers where the nutrition of women of reproductive age and children are monitored. In addition, contraceptives are made available here by family planning field workers. Information on the year of introduction of these sources of contraceptives was obtained mainly from the community leader. In case the community leader did not provide the information, responses of the head of the village women's group were used where available. Table 7 provides a cumulative distribution of the number of contraceptive clinics of each type that were introduced from 1979 until 1993 in all IFLS 1 EAs. Since I am interested in the impact of the expansion of the family planning program after 1979, it is of interest to note that $77 \%$ of the village integrated health posts, $58 \%$ of the family planning distribution points, and 33\% of the community health centers were introduced after 1979. Figure 7 provides information on the total number of facilities of each type that was introduced over time.

I model the decisions that women make in every period regarding contraceptive use and sector of employment to study the impact of the family planning program on their well-being between the years 1979 to 1993 . One of the problems in studying joint choices lies in determining the direction of causation. The endogeneity problem is that there may be individual unobserved heterogeneity that affects both contraceptive and employment decisions. If indeed the unobserved heterogeneity drives both decisions, it will lead to biased estimates. I 
use the exogenous variation in the timing of introduction of three types of contraceptive clinics in the different EAs to identify the causal relationship. ${ }^{34}$ These sources of variation in contraceptive availability make it easier to obtain contraceptives by lowering the costs of getting them, but there is no direct impact on labor force participation decisions. I also use the exogenous variation in minimum wage rates over time across provinces to identify parameters related to employment decisions. Variation in minimum wage rates does not directly affect choices women make regarding contraceptives.

\section{Estimation}

Solving the dynamic programming problem is not an easy task. The solution involves obtaining the value function for each person for each point in the state space for a given set of parameters. The value functions minus the choice-specific time shocks, $\bar{V}$, are required to construct the probability of the choice actually observed in the data. This, in turn, is used to compute the corresponding likelihood contribution. I can solve the dynamic programming problem by backward recursion because I assume that the horizon is finite. First, to reduce the computational cost of the dynamic programming problem, upper bounds are imposed on several state variables. Second, to further reduce the computational cost, I estimate the value function at only a subset of the points in the state space and interpolate the value function at the other points. I follow the weighting scheme used in Brien, Lillard, and Stern (2006). The value function has to be evaluated for each person in the sample for every guess of the parameter. In my model, individuals can differ by the following exogenous characteristics: religion (Muslim/Not Muslim), location (urban/rural), province (Java/Non-

\footnotetext{
${ }^{34}$ Evidence to show exogeniety of timing of introduction of contraceptive clinics and variation in minimum wage rates will be furnished upon request.
} 
Java), education (primary or less/more than primary school), and initial age of woman in 1979 (from 16 to 30). I use the interpolation method suggested by Brien, Lillard, and Stern (2006) to compute the value function array for $2 \cdot 2 \cdot 2 \cdot 2 \cdot 15=240$ representative people.

I estimate the birth probability function outside the structural model as a probit, where the dependent variable is one in the event of a birth and zero otherwise. To further reduce the costs of computation, I estimate the wage equation outside the structural model. To correct for selection bias when determining the impact of observables on wage rates, I model the selection process as a multinomial logit regression model.

After solving the dynamic problem and obtaining the parameters for the wage equation and birth probability function, then, with the data on observed choices and state variables, I estimate the parameters of the utility function and budget constraint by the method of maximum likelihood. The solution to the individual's optimization problem provides the choice probabilities in the likelihood equation. The sample likelihood equation is the product across individuals, time and, choices of the contributing probabilities corresponding to each alternative.

$$
L(.)=\prod_{i} \int \prod_{t} \operatorname{Pr}\left(\mu_{i}, t, \overline{S(t)}\right) d H\left(\mu_{i}\right)
$$

where $\operatorname{Pr}\left(\mu_{\mathrm{i}}, \mathrm{t}, \overline{S(t)}\right)$ is the likelihood contribution of a woman at a particular time $\mathrm{t}$, given $\mu_{\mathrm{i}}$ and $\overline{S(t)}$. Here $\overline{S(t)}$ is defined to be the part of the state vector without the wage errors.

Parameter estimates are obtained by maximizing the log-likelihood function using a numerical optimization routine. Particularly, since the likelihood function is complex I use the Berndt, Hall, Hall, and Hausman (1974) algorithm to maximize the log-likelihood function. 


\section{Structural Estimation Results}

\subsection{Female Wage Equation}

Recall that the wage equation is estimated outside the structural model in order to reduce the computational cost of estimating a full structural model. The wage parameters are taken as given in the structural model. Each period, wages are observed in the sector in which the woman works. To correct for selection bias when determining the impact of observables on wage rates, I model the selection process as a multinomial logit regression model. ${ }^{35}$ Consistent estimators of conditional expected values of residuals from the multinomial logit model are included as additional regressors in the wage regression. The coefficients on these terms show the covariance between the error term in the wage equation and some function of the residuals in the multinomial logit equation.

The probability of participation of a woman in each sector is a function of her education, sector-specific labor market experience, age, number of births, religion, birth in the previous period, whether the woman resides in an urban location, and age of her youngest child. The wage rate of a woman depends on age, urban location, minimum wage rates, education, and sector-specific experience. The wage rate of a woman who is not working is zero. Separate wage equations are estimated for both the formal and informal sector. This implies that characteristics such as education, age, and experience have differential impacts on the wage rates of women across sectors. Recall that the minimum wage should have no significant impact on wage rates in the informal sector, but affect wage rates in the formal sector.

Table 8 presents parameter estimates from the wage and selection equations for both the formal and informal sectors. 'Not working' is considered as the base category. The second and

\footnotetext{
${ }^{35}$ More specifically, I use Fournier and Girgand's (2004) user written SELMLOG program. See http \:www.pse.ens.fr \senior $\backslash$ gurgand $\backslash$ selmlog13.htm for code.
} 
third columns show the formal sector wage and selection equations. The fourth and fifth columns do the same for the informal sector.

Results suggest that participation of woman in the formal sector increases with age, education, and urban location. Estimates of the selection equations indicate that participation in the formal and informal sectors increases with sector-specific experience. This indicates benefits from sector-specific human capital accumulation or familiarity associated with working in the same sector. It is worth noting that, as age of youngest child increases, a woman is more likely to participate in the formal sector. This is consistent with the notion that it is easier for a woman to work outside the home as the child ages. Women with higher levels of education are more likely to participate in the formal sector, suggesting that it is the marginalized women who tend to work more in the informal sector. Participation in the informal sector also increases with age, work experience, and decreases if the woman is Muslim or lives in an urban area. A woman is more likely to participate in the informal sector as her youngest child becomes older and as she has more births.

As expected for the formal sector, experience in the formal sector and educations have a significant positive impact on wages. The province-level minimum wage rates have a positive impact on the wages of woman in the formal sector. In the informal sector, as expected, the province-level minimum wage rates do not have any significant impact on wages, as minimum wage laws are not enforced in the informal sector of the economy. Work experience does not have any significant impact on the wages in the informal sector.

\subsection{Birth Probability Function}

Recall that the birth probability function, like the wage equation, is estimated outside the structural model in order to reduce the computational load of estimating a full structural model. Table 9 presents the results of the probit estimation. The dependent variable takes the value one 
if a birth occurs in period $t$ and a value of zero otherwise. As expected, the likelihood of birth decreases with age of the woman. The probability of birth decreases with use of either modern or traditional methods of contraception, with modern methods of contraception having a stronger effect. The longer modern methods of contraception have been used, more effective they are in preventing pregnancies. The duration of use of traditional methods of contraception do not seem to have any significant impact on the probability of birth.

\subsection{Parameters of the Utility Function and Budget Constraint}

Recall that the decision-making period for a woman starts when she is first married. The final decisions are made in the year 1993. The highest number of years for which the decisions are observed is 15.36 For five years following 1993, a woman earns utility based on her last choice set. A caveat here is that some women are still young and will continue to earn utility from time-varying choices. Integrating later waves of the Indonesia Family Life Survey (2, 3, and 4) would allow me to observe choices made by a woman in later years all the way up to 2008 and, thereby, overcome this issue.

The discount factor is set to 0.90 in this model and not estimated. ${ }^{37}$ The identification of the results of the structural model is relative to a base choice of not using contraception and not working.

The structural estimates of the discrete choice dynamic model are presented in Table 10. The results in Table 10 are from the model specified in Section 4 minus unobserved heterogeneity and wage errors. The estimates should be interpreted as the additional utility flow, relative to the base choice of not working or not using contraceptives, resulting from a

\footnotetext{
${ }^{36}$ This covers women who marry in the year 1979.

${ }^{37}$ Previous literature (Berkovec and Stern 1991; Eckstein and Wolpin 1989; Van der Klaauw 1996) reports that it is difficult to estimate the discount factor with any precision. Assignment of the discount factor to be 0.90 is arbitrary.
} 
unit increase in the corresponding covariate. For example, a Muslim woman who works in the formal sector and uses modern methods of contraception has $(0.0211)+(-0.6530)=-0.6319$ units of utility less than her non-Muslim counterpart and this is relative to the base utility, which is same for all women.

\subsubsection{Estimates Associated with Contraception Method}

The structural estimates reveal that Muslim women enjoy higher utility flows from using modern contraception relative to their non-Muslim counterparts. ${ }^{38}$ This might reflect the Indonesian government's ability to convince Muslim religious leaders that population control promotes national interest. ${ }^{39}$ The estimates for the traditional method suggest the opposite. Women with more education enjoy greater utility from using modern methods of contraception relative to women who have no education or less than primary school education. This is consistent with the current literature that predicts that women with greater educational attainment are more likely to use contraceptives. This may be because of the following reasons: first, they may be more inclined to work in the formal sector (which involves less opportunity for joint production) ${ }^{40}$; second, they may be more informed about how to use the method; or, third, they may desire higher levels of education for their children, thus raising the cost per child. Women with more education enjoy less utility flow from traditional methods. Residing in urban areas compared to rural areas provides less utility flow from modern methods of contraception. The reverse is true for the utility flow experienced from traditional methods. Younger women experience less utility flow from modern methods compared to older women.

This may be because younger women are in the beginning phase of their child-bearing years

\footnotetext{
${ }^{38}$ This is without taking into account the interaction of employment sector and contraception method.

${ }^{39}$ In October 1983, almost 22 years ago, a national conference of the Ulama (local-level religious leaders), passed a resolution stating, "Islamic teachings justify family planning for the betterment of health conditions of mother and child, to make the child healthy, intelligent and devout." (Singh 2005). ${ }^{40}$ I do not control for the interaction of education and employment sector in the utility function.
} 
and may have a greater desire to have children. As age of the youngest child increases, a woman will receive less utility flow from using a modern method of contraception. This is consistent with reduced form findings that suggest that, as the youngest child of a woman grows older, a woman is less likely to use a modern method of contraception. This may be attributed to the willingness of women to have another child after sufficient spacing. Women who already have children enjoy higher utility flow from modern methods of contraception. This may have to do with the effectiveness of modern methods in reducing fertility. The estimates suggest positive duration dependence in using modern methods of contraception. This estimate may be biased to the extent that it is picking up a time-invariant preference for modern methods of contraception as opposed to a woman using modern methods because she either knows how or is comfortable with it because she has used modern methods in the past. The utility flow enjoyed by a woman increases in the presence of a community health center, village integrated health post, or family planning distribution point. This is likely to reflect reduction in cost that a woman faces in obtaining contraceptives as a result of easy access. If a woman had a birth in the previous period, she receives negative utility flow from using modern methods in the current period. This could be because a woman may be breast-feeding and hence believes she is less likely to get pregnant. This coefficient may be biased to the extent a woman knows about her innate fecundity. For instance, if a woman knows that she has trouble getting pregnant and it was after great amount of trying that did she get pregnant in the previous period, she might get negative utility from using modern methods of contraceptives.

\subsubsection{Estimates Associated with the Employment Sector}

The presence of children provides lower utility flow when a woman is working in the formal sector and higher utility flow when working in the informal sector. This suggests that informal sector jobs are compatible with household responsibilities (where number of children 
is a proxy for demand for woman's time and household responsibilities). As the number of births increases, the utility gains from working in the formal sector decrease .The utility flow that a woman enjoys from working in the formal sector increases as age of her youngest child goes up by one. This may arise, as the child gets older, the mother may be more comfortable leaving the child at home. ${ }^{41}$ There is positive duration dependence associated with working in the formal sector. This term may be capturing sector-specific human capital accumulation. The duration dependence associated with working in the informal sector is negative. This may be because jobs in the informal sector require very little skill and there is no benefit in working in the informal sector for a long time. The duration terms are capped at two years in the estimation in order to reduce computational costs. A woman experiences negative utility flow if she had a birth in the previous period and works in the formal sector. This might reflect difficulties new mothers face in leaving an infant at home when they go out to work. Being Muslim reduces the utility flow from formal sector employment. This may be because women working outside the house might not be widely accepted in Indonesia, a primarily Islamic society. Residing in an urban area compared to rural areas increases utility flow from working in the formal sector. There may be bias in this coefficient to the extent that there is endogenous migration to urban areas for formal sector employment.

\subsubsection{The Budget Constraint}

The coefficient associated with income, which is the marginal utility of consumption, is 0.067. The marginal utility of consumption is positive indicating that an increase in income increases utility flow. The consumption is measured in units of 0.1 million Indonesian Rupiah

\footnotetext{
${ }^{41}$ Recall that only age of youngest child is used instead of modeling ages of all children. This is done in order to reduce computational cost.
} 
(approximately US \$100), expressed in year 2005 Rupiah. ${ }^{42}$ A 0.1 million Rupiah increase in income increases utility by 0.067 utils. One util is equal to one standard deviation of the extreme value error (where parameter $\tau$ is given the value one). The coefficient on consumption implies that one unit of non-pecuniary utility is equal to $(1 / 0.067) * 100000=\operatorname{Rp} 1492537$. This is roughly equal to $\$ 149.23$.

\subsubsection{Other Parameter Estimates}

A woman experiences negative utility flow when she gives birth at an age greater than 35 years. This captures the physical difficulties that older women face in giving birth. She enjoys positive utility flow from having children. This may be as a result of satisfaction from being a mother, in addition to knowing that they have a form of additional security for old age. ${ }^{43} \mathrm{~A}$ woman enjoys positive utility flow when she gives birth. This suggests that the satisfaction from having a child is greater than the physical pain endured in having one. ${ }^{44}$

\section{Conclusion}

Structural model estimates indicate that informal sector jobs offer greater compatibility between work and childcare. Parameter estimates indicate that women with more kids and young kids receive more utility from working in the informal sector. Access to modern methods of contraception (presence of clinics) reduces cost of using modern methods. This increases its use and in turn, reduces likelihood of birth and number of births. This encourages participation of women in formal sector. Parameter estimates indicate that choices of

\footnotetext{
${ }^{42}$ In 2009, one US dollar is approximately equal to 10,000 Indonesian Rupiah. The Indonesian currency has been devalued several times in the past as a result of high levels of inflation.

${ }^{43}$ The monetary cost of raising children cannot be identified separately from the nonpecuniary utility associated with having children.

${ }^{44}$ I do not make any distinction between giving birth to a boy versus a girl in this model. Several studies (Kevane and Levine 2000) have shown that gender bias is not a problem in Indonesia.
} 
contraception method and employment sector vary by exogenous characteristics such as religion, urban or rural residence, presence of clinics and age of the woman. The number of kids a woman has, birth spacing, and age of youngest child seem to play an important role in impacting choices made by married women. ${ }^{45}$

Although the outcomes are observed at the individual level, this research provides insight into the impact that investments in family planning can have for the economy as a whole. Participation of women in the labor force increases per capita income and this translates into economic growth. Increases in female labor force participation may push down wage rates, holding everything else constant.

Several assumptions have been made in estimating the parameters of this model. The results must be looked at with the following caveats, some of which are avenues of future work: 1) Birth probability function and wage equation has been estimated outside the structural model; 2) The estimation of the structural model did not include unobserved heterogeneity terms. An important task to be performed in the future is to estimate the structural model with unobserved heterogeneity so as to determine how inherent taste affects choices that a woman makes; 3) It was assumed that that a woman receives offer from both sectors each period with certainty. Another task would be to estimate the probability that a woman receives offer from both sectors each period; 4) Incorporating migration decisions of a woman in the model may improve the model's ability to explain contraception choices of a woman; 5) Incorporating death of children in the model might explain why a woman has additional children; and 6) Modeling

\footnotetext{
45 I test the estimates of the structural model by performing a Chi-square goodness-of-fit test. I find that the model fits the data reasonably well. I also conduct specification tests to check for possible sources of misspecification in the model. The tests do not reveal any potential sources of model misspecification.
} 
this research in a bargaining framework may capture the role that men play in using contraception and deciding their wife's employment in a patriarchical society such as Indonesia. 


\section{References}

Adioetomo, Moertiningsish, Rani Toersilaningsih, Asmandi, Hendratno, Linda Fitriati, Elizabeth Eggleston, Karen Hardee, Terence Hull (1997). “Helping the Husband, Maintaining Harmony: Family Planning, Women's Work, and Women's Household Autonomy in Indonesia." Family Health International.

Bailey, Martha. J (2006). "More Power to the Pill: The Impact of Contraceptive Freedom on Women's Lifecycle Labor Supply." Quarterly Journal of Economics. 121(1): 289-320.

Berger, Marguerite and Myra Buvinic, editors (1989). Women's Ventures: Assistance to the Informal Sector in Latin America. Hartford: Kumarian Press.

Berkovec, James and Steven Stern (1991). “Job Exit Behavior of Older Men.” Econometrica. 59(1): 189-210.

Bernasek, Alexandra and Julie. H. Gallaway (2002). “Gender and Informal Sector Employment in Indonesia." Journal of Economic Issues. 36(2):313-321.

Berndt, E.K., B.H. Hall, R.E. Hall, and J.A Hausman (1974). “Estimation and Inference in Nonlinear Structural Models." Annals of Economic and Social Measurement. 3(4):653-665.

Bourguignon, François, Martin Fournier, and Marc Gurgand (2007). "Selection Bias Corrections Based on the Multinomial Logit Model: Monte Carlo comparisons." Journal of Economic Surveys. 21:174-205.

Brien, Michael, Lee Lillard and Steven Stern (2006). “Cohabitation, Marriage, and Divorce in a Model of Match Quality." International Economic Review. 47(2):451-494.

Browning, M, F Bourguignon, P .A Chiappori and V Lechene (1994). “Incomes and Outcomes: A Structural Model of Intrahousehold Allocation." Journal of Political Economy. 102(6): 1067-1096. 
Browning, M and P. A Chiappori (1998). “Efficient Intrahousehold Allocations: A General Characterization and Empirical Tests." Econometrica.66 (6):1241-1278.

Cain, Glen G and Martin D. Dooley (1976). “Estimation of a Model of Labor Supply, Fertility, and Wages of Married Women." The Journal of Political Economy. 84(4):179-200.

Cammack, Mark and Tim B. Heaton (2001). “Regional Variation in Acceptance of Indonesia's Family Planning Program." Population Research and Policy Review .20: 565-585.

Cohen, Allen J, Nathaniel Schenker, Trivellore E. Raghunathna, Pei-Lu Chiu, Diane M. Makuc, and Guangyu Zhang (2006). "Multiple Imputation of Missing Income Data in the National Health Interview Survey." Journal of the American Statistical Assoication. 101(475):924-933.

Carro, Jesus. M and Pedro Mira (2002). “A Dynamic Model of Contraceptive Choice of Spanish Couples." CEMFI.

Dubin, Jeffrey. A and Daniel L. McFadden (1984). "An Econometric Analysis of Residential Electric Appliance Holdings and Consumption." Econometrica. 52(2):345-362.

Easterlin, Richard. A and Eileen M. Crimmins (1985). The Fertility Revolution: A Supply-Demand Analysis. Chicago and London: The University of Chicago Press.

Eckstein, Zvi and Kenneth I. Wolpin (1989). “Dynamic Labor Force Participation of Married Women and Endogenous Work Experience." The Review of Economic Studies. 56(3): 375-390.

Engers, Maxim P. and Stern, Steven N (2002). "Long-Term Care and Family Bargaining." International Economic Review. 43, 73-114.

Fleisher, Belton. M and George F. Rhodes (1979). “Fertility, Women's Wage Rates, and Labor Supply." The American Economic Review. 69(1):14-24. 
Forste, Renata (1994). “The Effects of Breastfeeding and Birth Spacing on Infant and Child Mortality in Bolivia." Population Studies. 48(3): 497-511.

Francesconi, Marco (2002). "A Joint Dynamic Model of Fertility and Work of Married Women." Journal of Labor Economics. 20(2):336:380.

Frankenberg, Elizabeth, Bondan Sikoki, and Wayan Suriastini (2003). “Contraceptive Use in a Changing Service Environment: Evidence from Indonesia during the Economic Crisis." UC Los Angeles, On-Line Working Paper Series, California Center for Population Research.

Gallaway, Julie. H (2001). “Where Does She Find the Time? Essays on Women and Work in Two Southeast Asian Countries." Ph.D Dissertation, Colorado State University.

Gertler, Paul. J and John W. Molyneaux (1994). "How Economic Development and Family Planning Program Combined to Reduce Indonesian Fertility." Demography. 31(1):33-63.

Goldin, Claudia and Lawrence F. Katz (2002). “The Power of the Pill: Oral Contraceptives and Women's Career and Marriage Decisions." Journal of Political Economy. 110(4): 730-770.

Hardee, Karen, Elizabeth Eggleston and Terence Hull (1998). “Family Planning and Women's lives: A Synthesis of Findings." Indonesia: The Women's Studies Project.

Heckman, James (1979). “Sample Selection Bias as a Specification Error.” Econometrica. 47(1): 153-161.

Heckman, James. J (1981). “The Incidental Parameters Problem and the Problem of Initial Conditions in Estimating a Discrete Time-Discrete Data Stochastic Process," in C.F Manski and D. McFadden (eds), Structural Analysis of Discrete Data with Econometric Applications, 179-195. MIT Press: Cambridge, MA.

Heckman, James. J and Singer, B (1984). “A Method for Minimizing the Impact of Distributional Assumptions in Econometric Models for Duration Data." Econometrica. 52(2): 271-320. 
Hill, M. Anne (1983). "Female Labor Force Participation in Developing and Developed countries-Consideration of the Informal Sector." The Review of Economics and Statistics. 65(3): 459468.

Hotz, V. Joseph and Robert A. Miller (1988). “An Empirical Analysis of Life Cycle Fertility and Female Labor Supply." Econometrica. 56(1): 91-118.

Jaffe, A.J. and K. Azumi (1960). "The Birthrate and Cottage Industries in Underdeveloped Countries." Economic Development and Cultural Change. 9(1):52-63.

Jones, Gavin W. (2002). “The Changing Indonesian Household." Women in Indonesia: Gender, Equity and Development. Kathyrn Robinson and Sharon Bessell e.d. Singapore: Seng Lee Press.

Jones, Gavin W. (2003). "Family Planning, Demographic Change and Economic Development" in Two is Enough: Family Planning in Indonesia under the New Order 1968-1998, edited by Anke Niehof and Firman Lubis. Leiden: KLTV Press.

Jones, Patricia (1997). “The Impact of Minimum Wage Legislation in Developing Countries when Coverage is Incomplete." Center for the Study of African Economies.

Joshi, Shareen and Paul T. Schultz (2007). “Family planning as a Long Term Investment in Development." Discussion paper 951, Economic Growth Center, Yale University.

Keane, Michael. P and Kenneth L. Wolpin (1997). “The Career Decisions of Young Men.” The Journal of Political Economy. 105(3): 473-522.

Lubis, Firman (2003). "History and Structure of the National Family Planning Program" in Two is Enough: Family Planning in Indonesia under the New Order 1968-1998, edited by Anke Niehof and Firman Lubis. Leiden: KLTV Press. 
Lubis, Firman and Anke Niehof (2003). "Introduction" in Two is Enough: Family Planning in Indonesia under the New Order 1968-1998, edited by Anke Niehof and Firman Lubis. Leiden: KLTV Press.

Manning, Chria (1998). Indonesian Labor in Transition. United Kingdom: Cambridge University Press.

Michael, Kevane and Levine I. David (2000). "The Changing Status of Daughters in Indonesia." Working Paper Series No. C03-126. UC Berkeley: Center for International and Development Economics Research.

Miller, Grant (2005). “Contraception as Development? New Evidence from Family Planning in Colombia." NBER Working Paper, \# 11704.

Miller, Jane. E , James Trussell, Anne R. Pebley, Barbara Vaughan (1992). “Birth Spacing and Child Mortality in Bangladesh and the Philippines." Demography. 29(2): 305-318.

Mize, Lucy and Bryant Robey (2006). "Thirty-Five Year Commitment to Family Planning in Indonesia: BKKBN and USAID's Historic Partnership". Baltimore: Johns Hopkins Bloomberg School of Public Health/Center for Communications Programs.

Moffitt, Robert (1984). "Profiles of Fertility, Labor Supply and Wages of Married Women: A Complete Life Cycle Model." The Review of Economic Studies. 51(2):263-278.

Molyneaux, John W., S.P. Pandi, and S. Wibisono (1990). "Correlates of Contraceptive Method Choice in Indonesia." Population Studies in Sri Lanka and Indonesia Based on the 1987 Sri Lanka Demographic and Health Survey and the 1987 Indonesian National Contraceptive Prevalence Survey. Washington D.C: Population Council.

Montgomery, Mark (1988). "On the Determinants of Employer Demand for Part-Time Workers." Review of Economics and Statistics. 70(1): 122-117. 
Newman, John. L (1988). "A Stochastic Dynamic Model of Fertility." Research in Population Economics. (6). T.P Schultz, e.d Greenwich: JAI Press.

Pritchett, Lant. H (1994). “Desired Fertility and the Impact of Population Policies." Population and Development Review. 20(1):1-55.

Rama, Martin (2001). “The Consequence of Doubling Minimum Wage: The Case of Indonesia.” Industrial and Labor Relations Review. 64(4):864-881.

Rosenzweig, Mark R and Paul T. Schultz (1982). "Child Mortality and Fertility in Columbia." Health Policy and Education. 2:305-348.

Rosenzweig, Mark R and Paul T. Schultz (1985). “The Demand for and Supply of Births: Fertility and its Life Cycle Consequences." The American Economic Review. 75(5):992-1015.

Rosenzweig, Mark R and K. Wolpin (1986). “Evaluating the Effects of Optimally Distributed Public Programs: Child Health and Family Planning Interventions." American Economic Review. 76(3):470-482.

Rust, John (1987). “Optimal Replacement of GMC Bus Engines: An Empirical Model of Harold Zurcher." Econometrica. 55 (5): 999-1033.

Sanzenbacher, Geoffrey (2009). “Wage Growth and the Job Dynamics of Welfare Recipients." Job Market Paper, Boston College.

Schultz, Paul. T (1990). “Testing the Neoclassical Model of Family Labor Supply and Fertility." Journal of Human Resources. 25(4): 599-634.

Schultz, Paul. T (1994). “Human Capital, Family Planning, and their Effects on Population Growth." American Economic Review Papers and Proceedings 84(2):255-260. 
Shrestha, Ranjan (2007). “Family Planning, Community Health Interventions and the Mortality Risk of Children in Indonesia." Ph.D Dissertation, Ohio State University.

Simmons, Sarah (2008). "Welfare (to School?) to Work: How Welfare Reform Affects Collegiate Attainment." Ph.D Dissertation, University of Virginia.

Singh, Rahul (2005). "The Leader Article: Muslim countries show the way in birth control.” The Times of India.

Sylvester, Michelle Sheran (2007). "The Career and Family Decisions of Women." Review of Economic Dynamics. 10(3):367-399.

Thomas, Duncan, Dante Contreras, and Elizabeth Frankenberg (2002). “Distribution of Power within the Household and Child Health." Unpublished Manuscript, Rand Corporation, Santa Monica.

Tiefenthaler, Jill (1994). “A Multisector Model of Female Labor Force Participation: Empirical Evidence from Cebu Islands, Philippines." Economic Development and Cultural Change. 42(4): 719742.

Tjiptoherijanto, Prijono (1997). “Social, Economic and Demographic Trend in Indonesia during 1960-1994." In Migration and Family Planning. Report for the Asian Urban Institute of Kobe.

Todaro, Michael. P (2000). Economic Development. $7^{\text {th }}$ ed. Reading. MA: Addison Wesley Longman,Inc.

Van der Klaauw, W (1996). “Female Labor Supply and Marital Status Decisions: A Life-Cycle Model." Review of Economic Studies. 63:199-235.

Willis, Robert. J (1973). “A New Approach to the Economic Theory of Fertility Behavior.” The Journal of Political Economy. 81(2):14-64. 
Table 1: Labor Force Participation Rates by Gender in Rural and Urban Areas, Indonesia

\begin{tabular}{llll}
\hline & $\mathbf{1 9 7 1}$ & $\mathbf{1 9 8 0}$ & $\mathbf{1 9 9 0}$ \\
\hline Male & & & \\
Urban & 61.2 & 59.1 & 64.0 \\
Rural & 70.4 & 71.2 & 74.4 \\
Total & 68.7 & 68.5 & 71.1 \\
Female & & & \\
Urban & 22.5 & 24.2 & 31.6 \\
Rural & 34.2 & 35.2 & 42.2 \\
Total & 32.1 & 32.7 & 38.8 \\
Both Sexes & 49.9 & 50.2 & 54.7 \\
\hline
\end{tabular}

Notes: This table is quoted from Manning (1998).

Source: CBS, Population Censuses, 1980 and 1990.

Table 2: Number of Contraceptive Users in Different Provinces over Time (in millions)

\begin{tabular}{lllll}
\hline & $\mathbf{1 9 7 3 / 7 4}$ & $\mathbf{1 9 7 8 / 7 9}$ & $\mathbf{1 9 8 3 / 8 4}$ & $\mathbf{1 9 8 9 / 9 0}$ \\
\hline Java-Bali & 1.6 & 5 & 10.7 & 12.3 \\
Outer Islands 1 & & 0.5 & 3.1 & 4.5 \\
Outer Islands 2 & & & 0.5 & 1.6 \\
\hline Indonesia & 1.6 & 5.5 & 14.3 & 18.4 \\
\hline
\end{tabular}

Notes: This table is obtained from Shrestha (2007). Minor modifications have been made. Blanks indicate family planning program has not yet been introduced in that province.

Source: National Family Planning Coordinating Board (1992).

Table 3: Sample Construction ${ }^{46}$

\begin{tabular}{ll}
\hline Reject Criterion & Number Remaining \\
\hline & 4890 \\
Incorrect Age or Missing Age at child & 4538 \\
birth & 4505 \\
Incorrect Age of Marriage (Negative) & 4178 \\
Missing Education or Pregnancy & \\
Information & 2270 \\
Married before 1979 & 2067 \\
Data not available for all years &
\end{tabular}

Source: IFLS 1

${ }^{46}$ Some of the missing values have been imputed and therefore those observations are not dropped. 
Table 4: Distribution of the Sample of Women by Province in 1993

\begin{tabular}{llc}
\hline Province & Number of Women & Percentage \\
\hline North Sumatra & 197 & 9.53 \\
West Sumatra & 99 & 4.79 \\
South Sumatra & 116 & 5.61 \\
Lampung & 87 & 4.21 \\
DKI Jakarta & 213 & 10.30 \\
West Java & 331 & 16.01 \\
Central Java & 200 & 9.68 \\
DI Yogyakarta & 101 & 4.89 \\
East Java & 288 & 13.93 \\
Bali & 128 & 6.19 \\
West Nusa Tennegara & 121 & 5.85 \\
South Kalimantan & 96 & 4.64 \\
South Sulawesi & 90 & 4.35 \\
\hline Total & 2067 & 100 \\
\hline
\end{tabular}

Source: IFLS 1

Table 5: Descriptive Statistics

\begin{tabular}{lll}
\hline Variable & Mean & Standard Deviation \\
\hline
\end{tabular}

Sample of 2067 Women

Age at time of marriage*

$19.67 \quad 3.97$

Urban

$0.51 \quad 0.50$

Muslim

$0.86 \quad 0.35$

Sample of 20,707 woman-year observations

\begin{tabular}{|c|c|}
\hline Age* $^{*}$ & 24.20 \\
\hline Number of children & 2.44 \\
\hline Age of youngest child* & 2.07 \\
\hline Gives birth & 0.22 \\
\hline Duration in formal sector* & 2.62 \\
\hline Duration in informal sector* & 2.93 \\
\hline Duration not working* & 10.79 \\
\hline Duration using modern methods* & 2.37 \\
\hline Duration using traditional methods* & 0.10 \\
\hline Duration not using contraceptives* & 4.47 \\
\hline
\end{tabular}

Notes: * denotes unit of measurement is year.

Source: IFLS 1 
Table 6: Distribution of Woman-Year Observations by Choices Made

\begin{tabular}{lc}
\hline Choice & Percentage \\
\hline Modern Method and Formal Sector & 9.17 \\
Modern Method and Informal Sector & 7.44 \\
Modern Method and Not Working & 23.82 \\
Traditional Method and Formal Sector & 0.96 \\
Traditional Method and Informal Sector & 0.55 \\
Traditional Method and Not Working & 1.80 \\
No Contraceptives and Formal Sector & 10.14 \\
No Contraceptives and Informal Sector & 10.78 \\
No Contraceptives and Not Working & 35.33 \\
\hline Total & 100 \\
\hline
\end{tabular}

Source: IFLS 1

Table 7: Cumulative Totals of Number of EAs with Access to Different Sources of Contraceptives over Time

\begin{tabular}{llll}
\hline Year & $\begin{array}{l}\text { Village Integrated } \\
\text { Health Posts }\end{array}$ & $\begin{array}{l}\text { Community } \\
\text { Health Center }\end{array}$ & $\begin{array}{l}\text { Family Planning } \\
\text { Distribution } \\
\text { Points }\end{array}$ \\
\hline Before 1980 & 42 & 175 & 104 \\
1980 & 74 & 192 & 134 \\
1981 & 83 & 203 & 146 \\
1982 & 98 & 214 & 151 \\
1983 & 135 & 231 & 172 \\
1984 & 170 & 236 & 190 \\
1985 & 205 & 246 & 215 \\
1986 & 241 & 254 & 240 \\
1987 & 263 & 257 & 259 \\
1988 & 280 & 261 & 271 \\
1989 & 295 & 267 & 283 \\
1990 & 302 & 274 & 291 \\
1991 & 307 & 280 & 298 \\
1992 & 309 & 285 & 303 \\
1993 & 312 & 286 & 309 \\
\hline S0 & & &
\end{tabular}

Source: IFLS 1 
Table 8: Wage and Selection Equations

\begin{tabular}{|c|c|c|c|c|}
\hline \multirow[t]{3}{*}{ Variable } & \multirow{2}{*}{\multicolumn{2}{|c|}{ Formal Sector }} & \multirow{2}{*}{\multicolumn{2}{|c|}{ Informal Sector }} \\
\hline & & & & \\
\hline & Selection & $\begin{array}{l}\text { Wage } \\
\text { Equation }\end{array}$ & Selection & $\begin{array}{l}\text { Wage } \\
\text { Equation }\end{array}$ \\
\hline Age & $\begin{array}{l}0.1000^{*} \\
(0.0067)\end{array}$ & $\begin{array}{l}-1904.573^{*} \\
(676877)\end{array}$ & $\begin{array}{l}0.0240^{*} \\
(0.0078)\end{array}$ & $\begin{array}{l}247.4801 \\
(277.0989)\end{array}$ \\
\hline Duration in Formal sector & $\begin{array}{l}0.5104^{*} \\
(0.0165)\end{array}$ & $\begin{array}{l}4624.41^{*} \\
(405.217)\end{array}$ & $\begin{array}{l}0.1135^{*} \\
(0.0254)\end{array}$ & $\begin{array}{l}2863.952 \\
(3561.547)\end{array}$ \\
\hline Duration in Informal Sector & $\begin{array}{l}0.3218^{*} \\
(0.0273)\end{array}$ & $\begin{array}{l}6874.014 \\
(6773.03)\end{array}$ & $\begin{array}{l}0.7419^{*} \\
(0.0223)\end{array}$ & $\begin{array}{l}-2880.7679 \\
(1567.33)\end{array}$ \\
\hline Muslim & $\begin{array}{l}-0.1527 \\
(0.0762)\end{array}$ & & $\begin{array}{c}-0.6159^{*} \\
(0.0835)\end{array}$ & \\
\hline Primary Education or less & $\begin{array}{l}-0.5552^{*} \\
(0.00558)\end{array}$ & $\begin{array}{l}-7731.157^{*} \\
(715.549)\end{array}$ & $\begin{array}{l}0.1751^{*} \\
(0.0696)\end{array}$ & $\begin{array}{l}3613.176^{*} \\
(1625.017)\end{array}$ \\
\hline Number of Births & $\begin{array}{l}-0.3059^{*} \\
(0.0268)\end{array}$ & & $\begin{array}{l}0.0968^{*} \\
(0.0285)\end{array}$ & \\
\hline Age of Youngest Child & $\begin{array}{l}0.0037^{*} \\
(0.0130)\end{array}$ & & $\begin{array}{l}0.0590^{*} \\
(0.0146)\end{array}$ & \\
\hline Urban & $\begin{array}{l}0.0204 \\
(0.0580)\end{array}$ & $\begin{array}{l}25096.03^{*} \\
(7492.266)\end{array}$ & $\begin{array}{l}-1.3301^{*} \\
(0.0681)^{*}\end{array}$ & $\begin{array}{l}6149.699 \\
(6022.922)\end{array}$ \\
\hline $\begin{array}{l}\text { Province level Minimum Wage } \\
\text { Rates }\end{array}$ & & $\begin{array}{l}3279.67^{*} \\
(130.7086)\end{array}$ & & $\begin{array}{l}1631.284 \\
(1247.175)\end{array}$ \\
\hline Constant & $\begin{array}{l}-3.3125 \\
(0.1793)\end{array}$ & $\begin{array}{l}81159.43 \\
(44347.2)\end{array}$ & $\begin{array}{l}-1.5220^{*} \\
(0.2000)\end{array}$ & $\begin{array}{l}-5849.197 \\
(1750.38)\end{array}$ \\
\hline $\begin{array}{l}\text { Conditional Expected Value of } \\
\text { Residuals }\end{array}$ & & & & \\
\hline Formal Sector & & $\begin{array}{l}0.4958^{*} \\
(0.1554)\end{array}$ & & \\
\hline Informal Sector & & & & $\begin{array}{l}-0.0872 \\
(0.2481)\end{array}$ \\
\hline
\end{tabular}

Notes: Statistical significance at $5 \%$ is indicated by *

Wages are in 2005 Indonesian Rupiah. 
Table 9: Birth Probability Function

\begin{tabular}{ll}
\hline Variable & Estimate \\
\hline Age of Woman & $-0.0109^{*}$ \\
Lagged Modern Method & $(0.0021)$ \\
& $-0.5655^{*}$ \\
Lagged Traditional Method & $(0.0574)$ \\
Duration of Modern method ** & $-0.3438^{*}$ \\
& $(0.1262)$ \\
Duration of Traditional Method ** & $-0.0885^{*}$ \\
Constant & $(0.0182)$ \\
& -0.087 \\
& $(0.0468)$ \\
\end{tabular}

Note: Statistical significance at $5 \%$ is indicated by *.

**Duration terms are for duration of the method used in the previous period.

Dependent variable takes the value 1 if the woman had a birth in period $t$. 
Table 10: Results of Structural Estimation

\begin{tabular}{|c|c|c|}
\hline Variable & Estimates & Standard Error \\
\hline \multicolumn{3}{|l|}{ Modern Method of Contraception } \\
\hline Age of Woman & $0.3103^{*}$ & 0.0022 \\
\hline Religion (Muslim) & $0.0211^{*}$ & 0.0019 \\
\hline Education & $0.0522^{*}$ & 0.0081 \\
\hline Urban & $-0.2105^{*}$ & 0.0054 \\
\hline $\begin{array}{l}\text { Presence of Village Integrated Health } \\
\text { Posts }\end{array}$ & $0.4218^{*}$ & 0.0439 \\
\hline Presence of Community Health Center & $0.2013^{*}$ & 0.0087 \\
\hline Presence of Family Planning & $0.3321^{*}$ & 0.0309 \\
\hline \multicolumn{3}{|l|}{ Distribution Points } \\
\hline Age of Youngest Child & $-0.1447^{*}$ & 0.0030 \\
\hline Birth in the previous period & $-0.0022^{*}$ & 0.0008 \\
\hline Number of births & $1.4528^{*}$ & 0.0687 \\
\hline Duration of modern method & $0.8891^{*}$ & 0.0992 \\
\hline Constant & $1.8904^{*}$ & 0.0321 \\
\hline Java and Bali & 1.4429 & 1.2208 \\
\hline \multicolumn{3}{|l|}{ Traditional Method of Contraception } \\
\hline Age of Woman & 0.0203 & 0.0220 \\
\hline Religion (Muslim) & $-0.0015^{*}$ & 0.0003 \\
\hline Education (More than primary) & $-0.041^{*}$ & 0.0048 \\
\hline Urban & $0.0021^{*}$ & 0.0007 \\
\hline $\begin{array}{l}\text { Presence of Village Integrated Health } \\
\text { Posts }\end{array}$ & 0.0002 & 0.0080 \\
\hline Presence of Community Health Center & 0.0036 & 0.0200 \\
\hline Presence of Family Planning & 0.0031 & 0.0740 \\
\hline \multicolumn{3}{|l|}{ Distribution Points } \\
\hline Age of Youngest Child & -0.0052 & 0.0043 \\
\hline Birth in the previous period & $0.0013^{*}$ & 0.0009 \\
\hline Number of births & $0.0237^{*}$ & 0.0082 \\
\hline Duration of traditional method & 0.0019 & \\
\hline Constant & $-0.3223^{*}$ & 0.0904 \\
\hline Java and Bali & 0.0066 & 0.0426 \\
\hline \multicolumn{3}{|l|}{ Formal Sector } \\
\hline Age of Woman & $1.5672^{*}$ & 0.3050 \\
\hline Religion (Muslim) & $-0.6530^{*}$ & 0.0623 \\
\hline Urban & $0.2059^{*}$ & 0.0865 \\
\hline Age of Youngest Child & $1.2887^{*}$ & 0.0741 \\
\hline Birth in the previous period & $-2.6549^{*}$ & 0.0927 \\
\hline
\end{tabular}




\begin{tabular}{|c|c|c|}
\hline Number of births & $-1.7381^{*}$ & 0.0373 \\
\hline Duration in formal sector & $0.8539^{*}$ & 0.0092 \\
\hline Constant & 2.4314 & 0.0865 \\
\hline Java and Bali & $1.002^{*}$ & 0.0004 \\
\hline \multicolumn{3}{|l|}{ Informal Sector } \\
\hline Age of Woman & $0.8991^{*}$ & 0.0032 \\
\hline Religion (Muslim) & $1.009^{*}$ & 0.0059 \\
\hline Urban & $-0.0038^{*}$ & 0.0004 \\
\hline Age of Youngest Child & $-0.0012^{*}$ & 0.0001 \\
\hline Birth in the previous period & $0.032^{*}$ & 0.0018 \\
\hline Number of births & $1.535^{*}$ & 0.0665 \\
\hline Duration in informal sector & -0.0786 & 0.0540 \\
\hline Constant & $1.4220^{*}$ & 0.0081 \\
\hline Java and Bali & $-0.9928^{*}$ & 0.0027 \\
\hline \multicolumn{3}{|l|}{ Other variables } \\
\hline Disutility from birth when age $>35$ & $-0.2035^{*}$ & 0.0009 \\
\hline Utility from birth spacing & $0.0311^{*}$ & 0.0068 \\
\hline Utility from birth & $0.0008^{*}$ & 0.0000 \\
\hline Benefit from children & $0.019 *$ & 0.0002 \\
\hline \multicolumn{3}{|l|}{ Consumption } \\
\hline Marginal Utility of Consumption & 0.067 & 0.0000 \\
\hline
\end{tabular}

Note: Statistical significance at $5 \%$ is indicated by *. 
Figure 1: Total Fertility Rate in Indonesia, 1965-70 to 2000-02

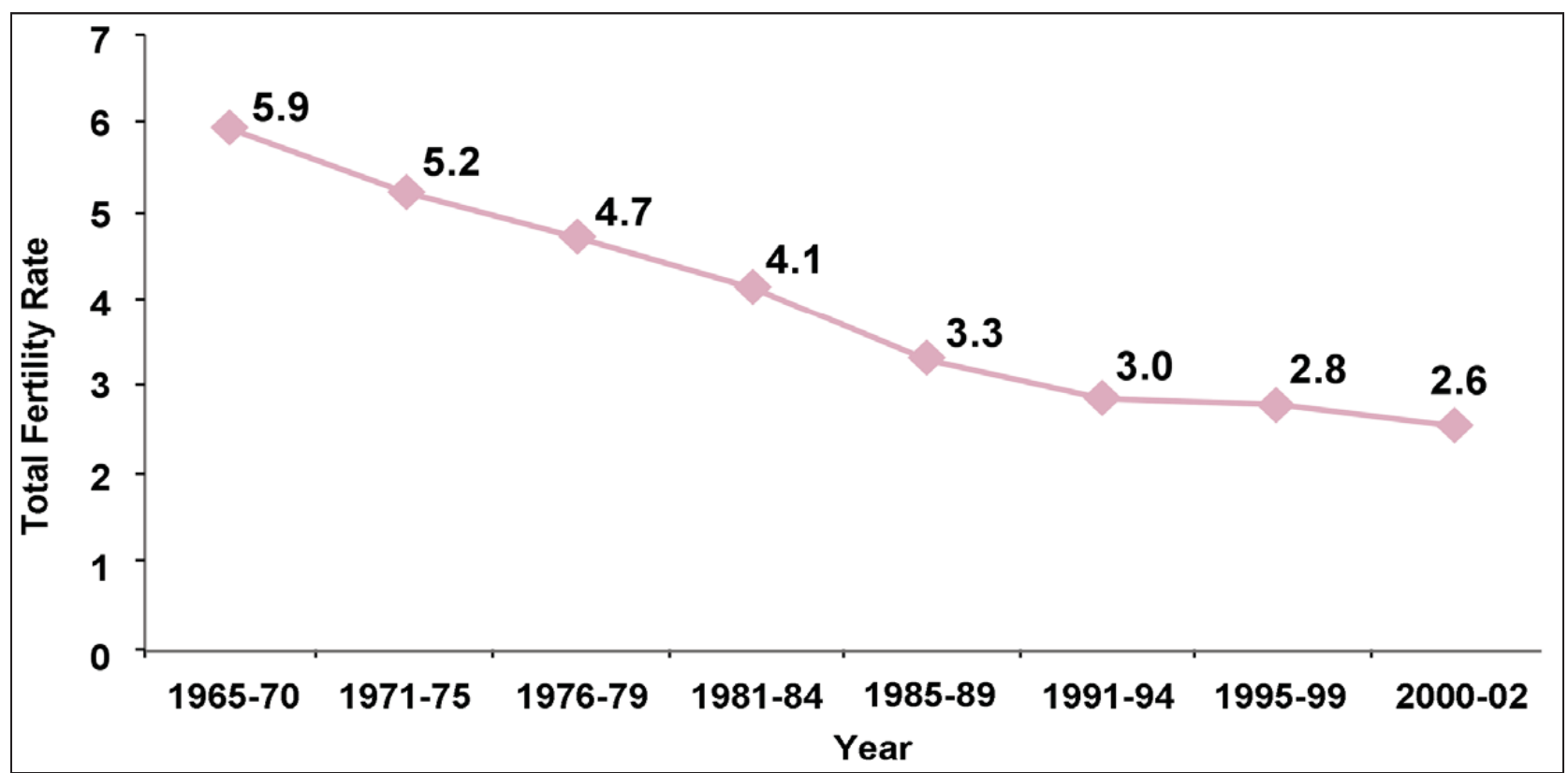

Notes: This figure is from Mize (2006).

Source: Contraceptive Prevalence Survey (1987) and Indonesian Demographic and Health Survey (1991, 1994, 1997, 2002-2003) 
Figure 2: Contraceptive Prevalence Rate in Indonesia, 1977-2006

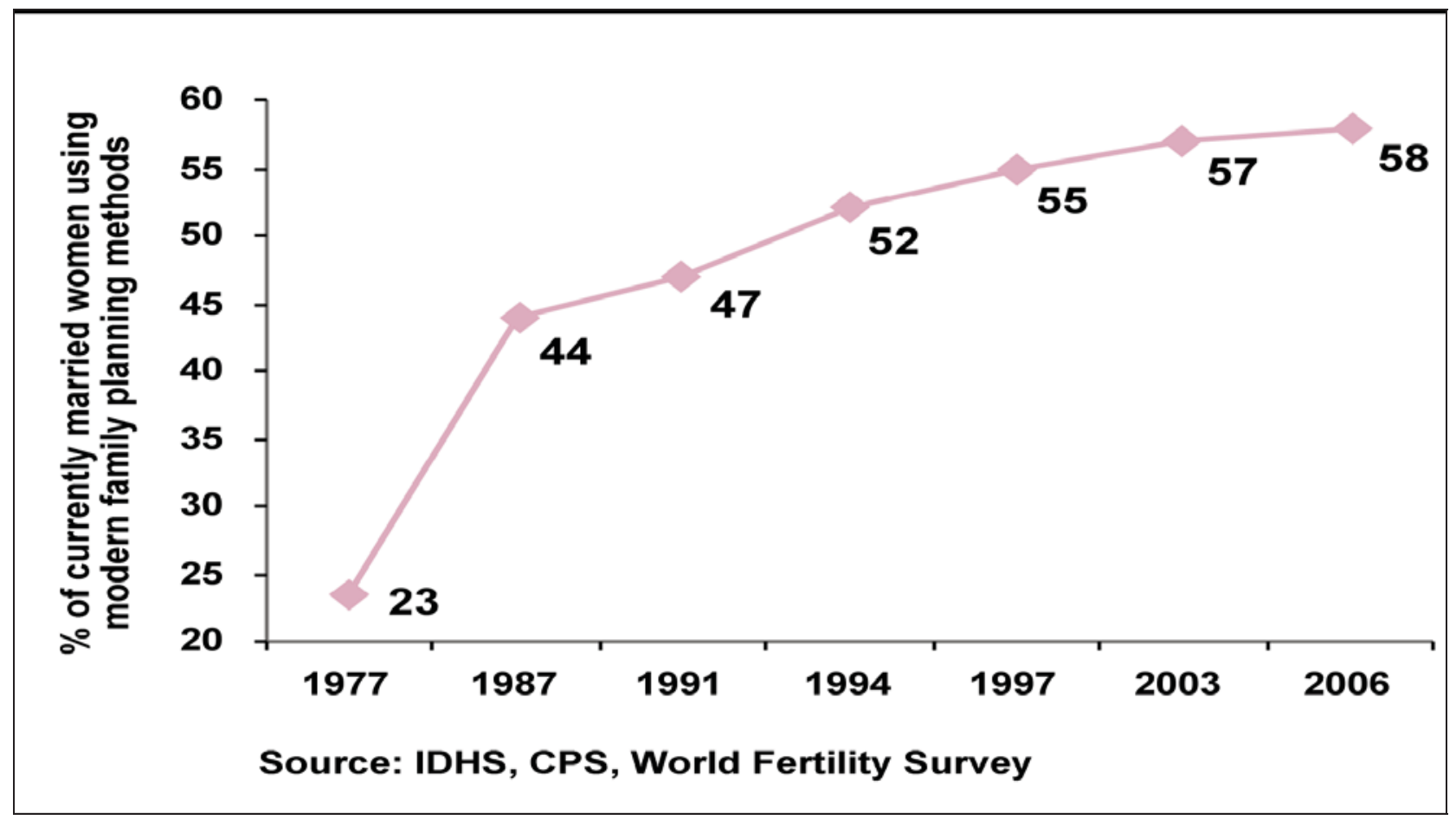

Notes: This figure is from Mize (2006). 
Figure 3: Phase 1 of the Indonesian Family Planning Program as Part of First FiveYear Development Plan

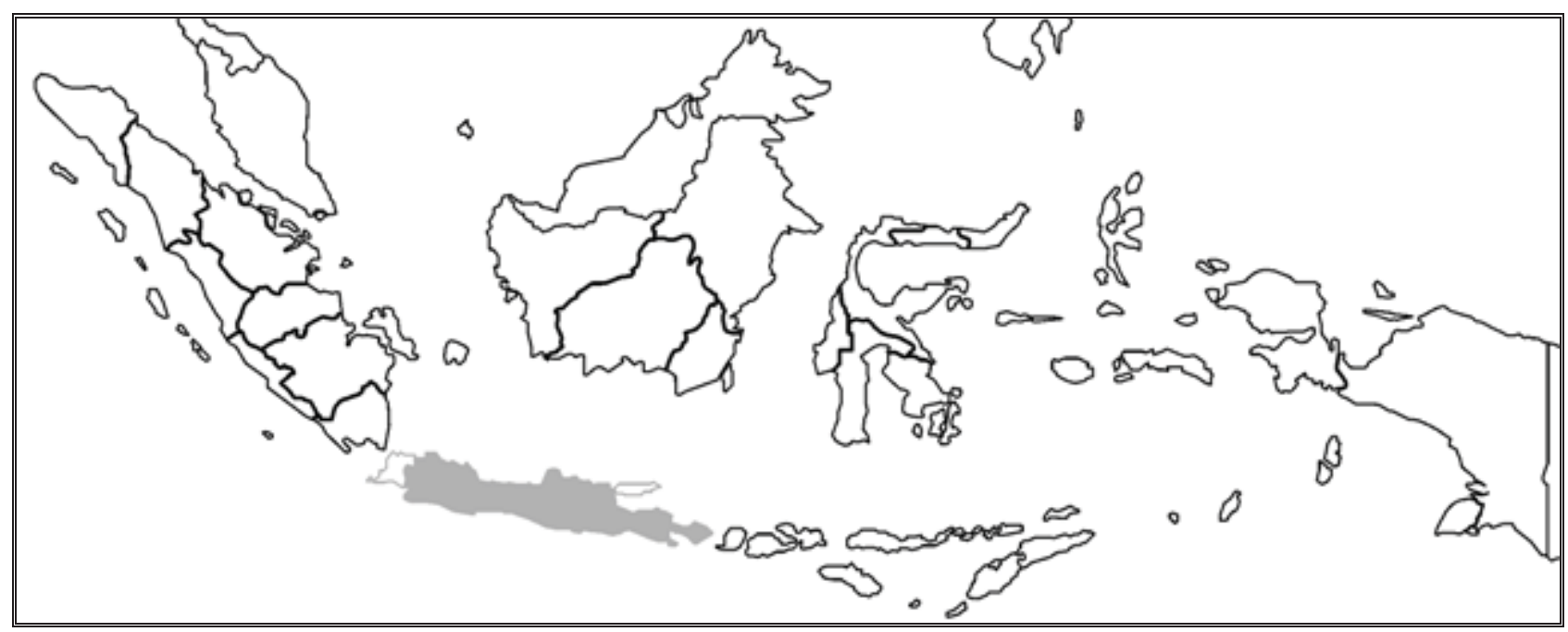

Notes: Shaded regions indicate provinces where the clinic-based approach of family planning was newly introduced: West Java, Jakarta, Central Java, East Java, Yogyakarta, and Bali. These regions adopted a community-approach of family planning in addition to a clinic-based one during phase 2. 
Figure 4: Phase 2 of the Indonesian Family Planning Program as Part of Second Fiveyear Development plan

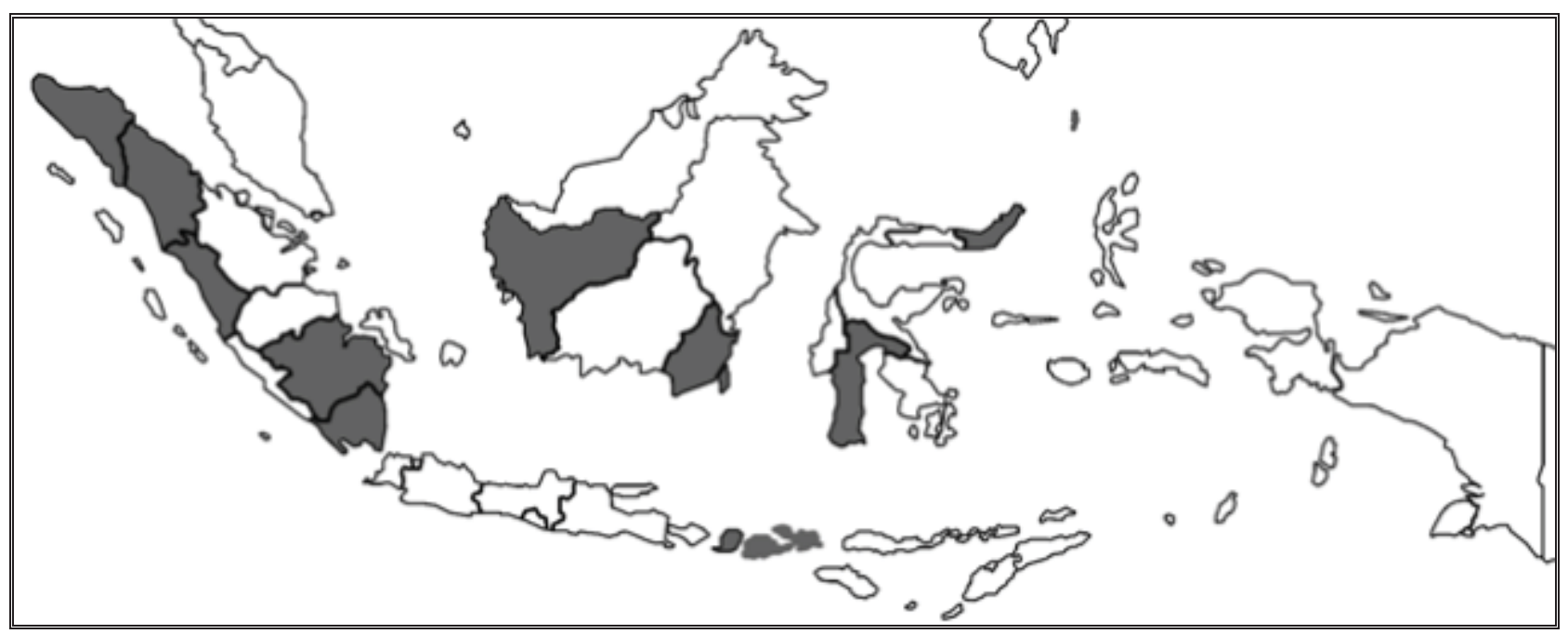

Notes: Shaded region indicates the 10 provinces where family planning was newly introduced: Aceh, North Sumatra, West Sumatra, South Sumatra, Lampung, North Sulawesi, South Sulawesi, South Kalimantan, West Kalimanatan, and West Nusa Tenggara. Regions from phase 1 that moved to community-based approach have not been shaded here. 
Figure 5: Phase 3 of the Indonesian Family Planning Program as Part of Third Fiveyear Development plan

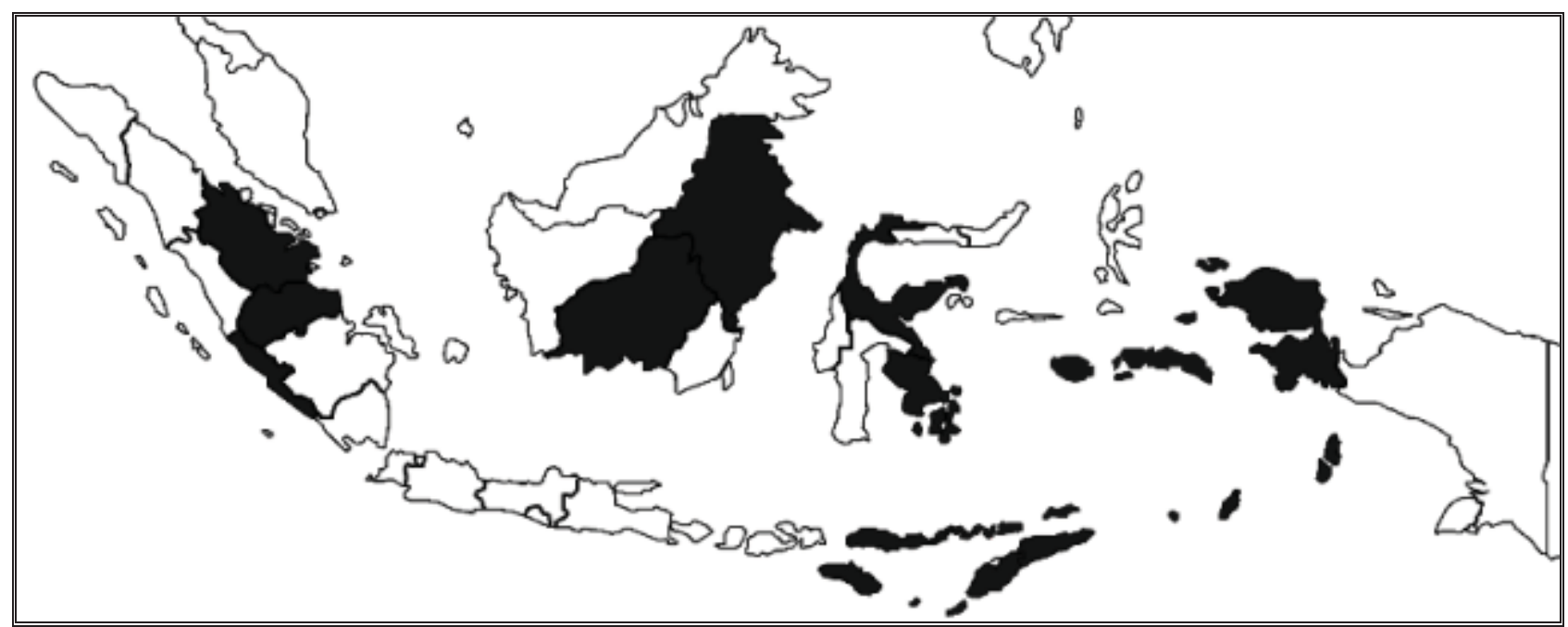

Notes: Shaded regions denote provinces in which family planning program was newly introduced: Riau, Jambi, Bengkulu, East Nusa Tenggara, Central Kalimantan, East Kalimantan, Central Sulawesi, South East Sulawesi, Maluku, Irian Jaya, and East Timor. Shaded regions do not include provinces from phase 1 and phase 2 that may have adopted new approaches to family planning. 
Figure 6: IFLS 1 Provinces

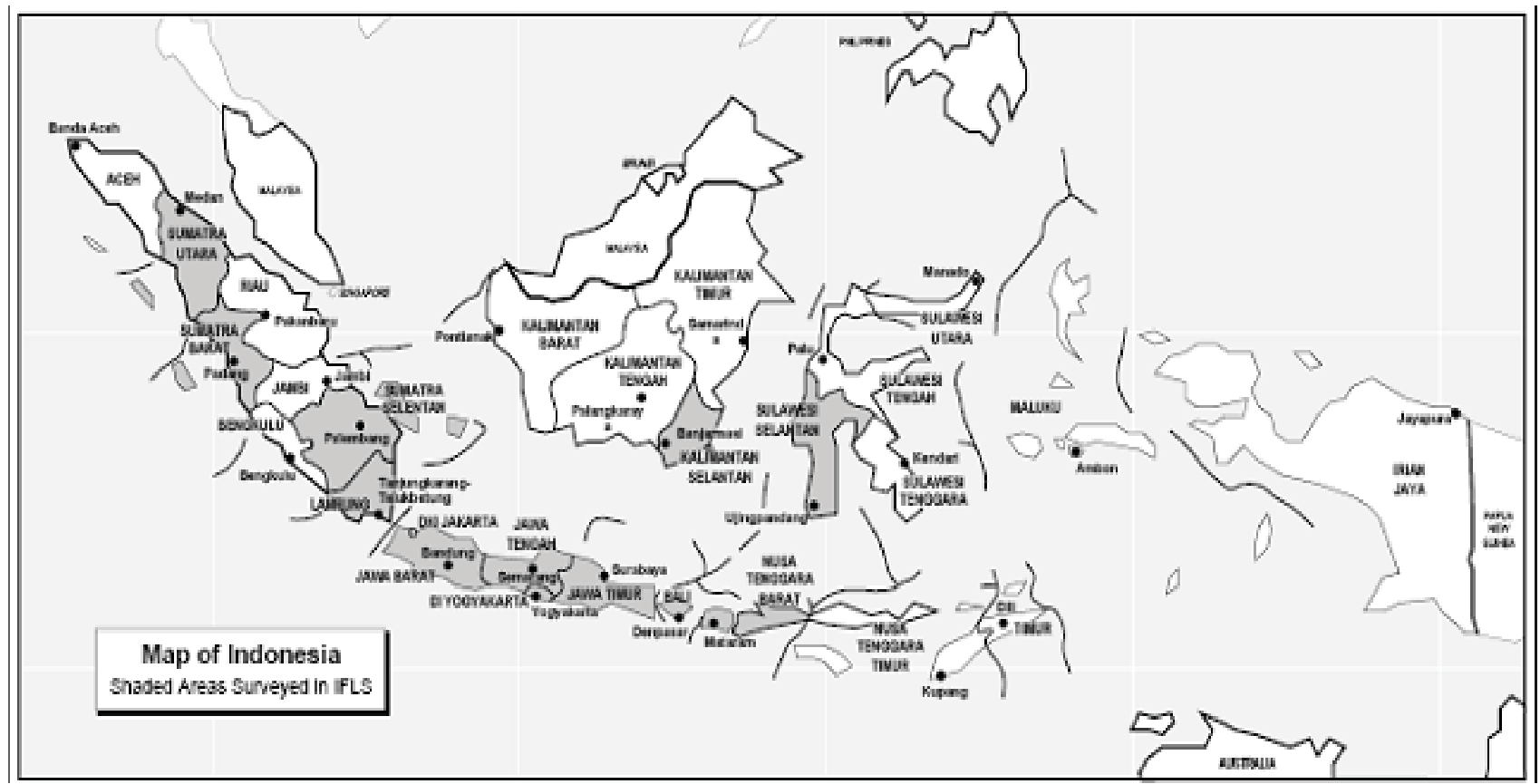

Source: IFLS 1 
Figure 7: Number of Family Planning Clinics Introduced during 1980-93
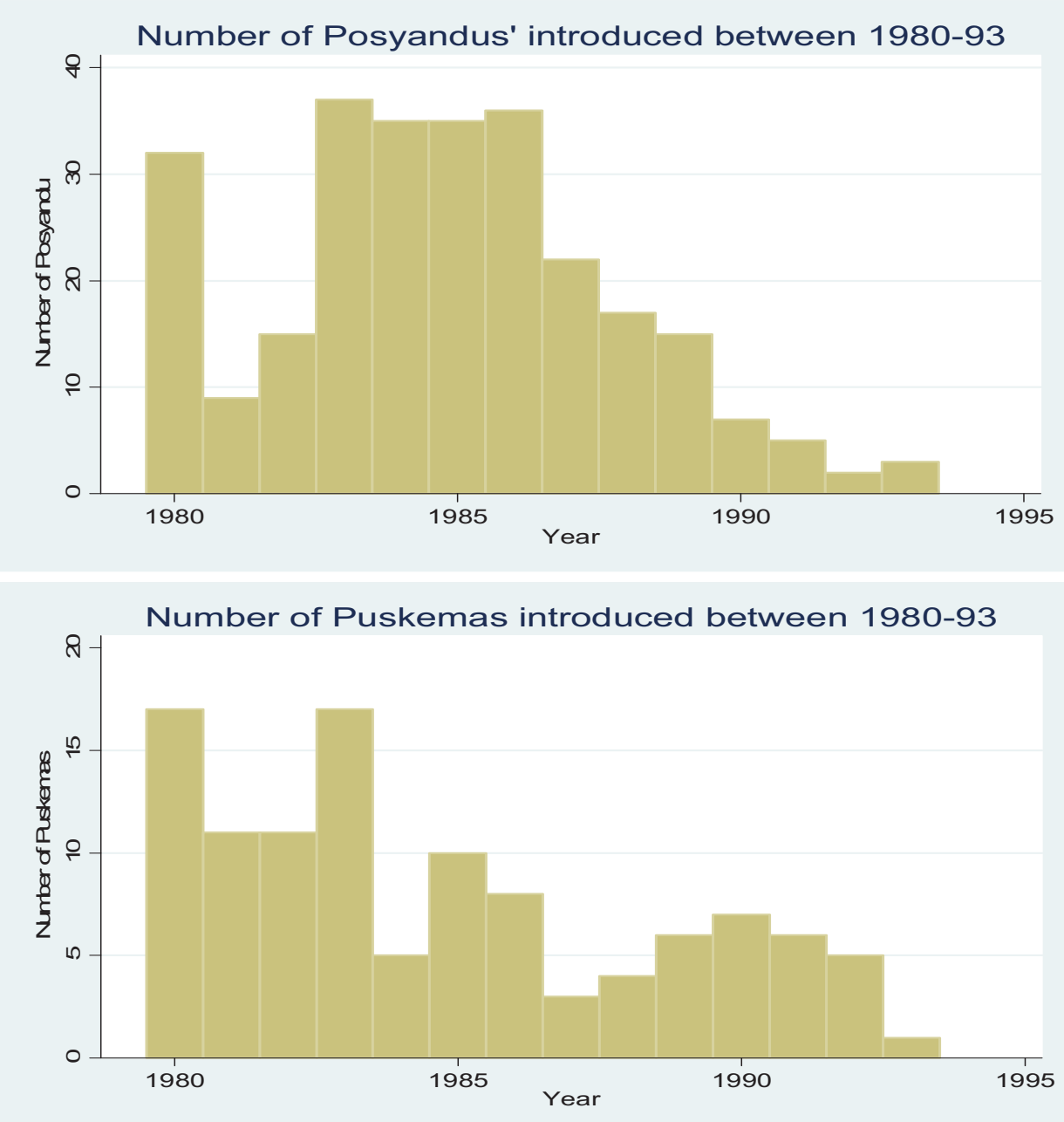

Continued.. 


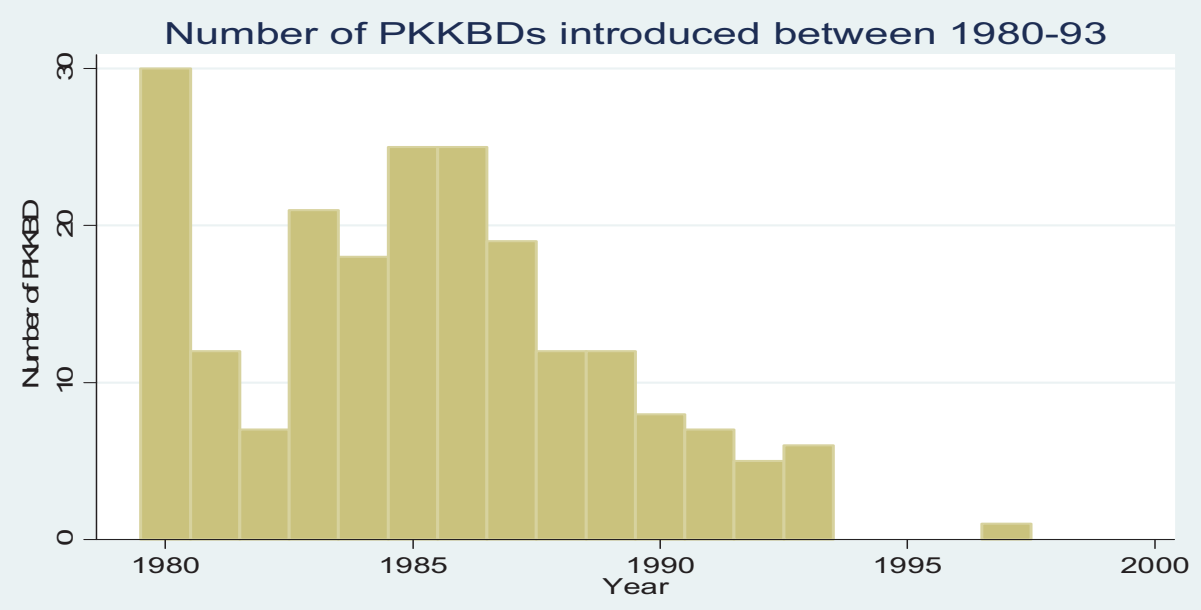

Notes: Posyandu is Village Integrated Health Post. Puskemas is Community Health Center. PKKBD is Family Planning Distribution Points. Source: IFLS1 